\title{
Endogenous Control Mechanisms of FAK and PYK2 and Their Relevance to Cancer Development
}

\author{
Rayan Naser ${ }^{\dagger}$, Abdullah Aldehaiman ${ }^{\dagger}$, Escarlet Díaz-Galicia ${ }^{+}$(i) and Stefan T. Arold * \\ King Abdullah University of Science and Technology (KAUST), Computational Bioscience Research Center (CBRC), \\ Division of Biological and Environmental Sciences and Engineering (BESE), Thuwal 23955-6900, Saudi Arabia; \\ rayan.naser@kaust.edu.sa (R.N.); Abdullah.aldehaiman@kaust.edu.sa (A.A.); \\ miriam.diazgalicia@kaust.edu.sa (E.D.-G.) \\ * Correspondence: stefan.arold@kaust.edu.sa; Tel.: +966-12-808-2557 \\ + Contributed equally.
}

Received: 7 May 2018; Accepted: 6 June 2018; Published: 11 June 2018

\begin{abstract}
Focal adhesion kinase (FAK) and its close paralogue, proline-rich tyrosine kinase 2 (PYK2), are key regulators of aggressive spreading and metastasis of cancer cells. While targeted small-molecule inhibitors of FAK and PYK2 have been found to have promising antitumor activity, their clinical long-term efficacy may be undermined by the strong capacity of cancer cells to evade anti-kinase drugs. In healthy cells, the expression and/or function of FAK and PYK2 is tightly controlled via modulation of gene expression, competing alternatively spliced forms, non-coding RNAs, and proteins that directly or indirectly affect kinase activation or protein stability. The molecular factors involved in this control are frequently deregulated in cancer cells. Here, we review the endogenous mechanisms controlling FAK and PYK2, and with particular focus on how these mechanisms could inspire or improve anticancer therapies.
\end{abstract}

Keywords: dimerization; miRNA; motility; anoikis; chaperon; PTEN; FIP200; LKB1; PI3K; regulation

\section{Introduction}

Focal Adhesion Kinase (FAK) is a multi-domain non-receptor protein tyrosine kinase (PTK) found in metazoans and also in the unicellular eukaryote Capsaspora owczarzaki [1,2]. FAK is a multifunctional protein that integrates and transduces signals perceived through integrin or growth-factor receptors into cytoplasmic and nuclear responses. This mechanism allows FAK to link the functions of adhesion, migration and survival in cells [3,4]. In particular, FAK is an essential factor in embryogenesis and wound healing due to its ability to override apoptosis following cell detachment (anoikis). While present in low levels in most adult tissues, FAK is overexpressed in most types of cancer in which its capacity to override anoikis and to drive cell motility promotes aggressive invasiveness and metastasis of cancer cells [5-8]. The observation that overexpression of FAK is linked to tumor invasiveness has made FAK a promising target for small-molecule inhibitors [7,9]. Although targeting FAK alone had only limited success in a clinical setting, initial proof-of-principle studies have highlighted that inhibition of FAK not only reduces tumor spreading, but it also makes cancer cells more susceptible to chemotherapy $[10,11]$. Indeed, FAK activity appears to trigger survival mechanisms under various stress conditions, such as DNA damage or immunological stress [10]. Consequently, promising preclinical results were obtained when FAK inhibitors were administered in combination with BRAF inhibitors or used jointly with chemotherapy, radiotherapy [12] or immunotherapy $[13,14]$. These combined approaches are now being tested in the clinical settings and are reviving interest in FAK inhibitors that waned due to the limited efficacy of targeting FAK in single-agent therapies.

Improved or novel FAK inhibitors may have a positive impact in combined approaches, because most available FAK inhibitors lack specificity and/or efficacy, and their precise molecular mechanism remains 
in many cases poorly defined [10]. Moreover, proline-rich tyrosine kinase 2 (PYK2), a close paralogue to FAK in vertebrates [15], can often functionally compensate for loss of FAK, and may thus override therapeutic inhibition of FAK in tumors [16,17]. Although similar in structure and function, FAK and PYK2 differ in their tissue distributions. Whereas FAK is widely expressed, PYK2 is expressed mostly in the brain, osteoclasts, macrophages and lymphocytes [18]. Despite their functional redundancy in many settings, FAK and PYK2 can also play different or even opposing cellular roles. For example, activation of FAK promotes cell cycle progression and survival, whereas activation of PYK2 generally inhibits such events [5,19-24]. Hence, under some circumstances (tissue-) specific inhibition of FAK or PYK2 might help an inhibitor to achieve desired therapeutic effects.

In this review, we summarize current understanding of the endogenous mechanisms used by cells to contain aberrant FAK and PYK2 activity. Thorough understanding of these mechanisms might lead to the design of new or improved therapeutic interventions that could block aggressive spreading of cancer cells. The multitude of cellular functions and locations of FAK and PYK2 have been comprehensively described in recent reviews [25-28]. We thus only briefly outline the general molecular mechanism for FAK and PYK2 activation. We particularly focus our review on how this mechanism is controlled by cellular factors, including alternatively spliced forms, interacting proteins and non-coding RNAs. We also discuss if and how the current knowledge of endogenous control mechanisms of FAK and/or PYK2 could improve the development anti-cancer strategies.

\section{Mechanistic Bases for Activation of FAK and PYK2}

PYK2 evolved from FAK through gene duplication and subsequent specialization in vertebrates [15]. In humans, both proteins share $46 \%$ sequence identity ( $65 \%$ similarity) and have the same three-domain organization [25,28,29]: an N-terminal band 4.1, ezrin, radixin, moesin (FERM) domain, a central catalytic kinase domain and a C-terminal focal adhesion targeting (FAT) domain (reviewed in detail by $[26,28,30]$. The domains are connected by long linkers that also contain important protein binding sites (Figure 1) [28,31,32]. Owing to the common origin and high sequence similarity of FAK and PYK2, the basic mechanisms for the (in)activation of one likely remain conserved in the other.

Both FAK and PYK2 harbor binding sites for many proteins (more than 50 have been described for FAK [26]) and nuclear localization and export signals [33,34]. These interaction sites allow FAK and PYK2 to function as molecular scaffolds. For a subset of their functions, the scaffolding function is sufficient, and kinase activity is not required $[35,36]$. In FAK, the FERM domain can directly bind to the kinase domain and inhibit its function [31]. Key residues for the FERM:kinase interaction are conserved between FAK and PYK2 (in particular FAK F596/PYK2 F599; [26]), suggesting that this FERM:kinase association also exists in PYK2. Experimental evidence for this association in PYK2 is, however, lacking [37-39]. In both proteins, kinase activity is generally initiated by autophosphorylation of a tyrosine situated in the FERM-kinase linker (FAK Y397 and PYK2 Y402). Together with the proline-rich region 1 (PR1) situated upstream in the same linker, the phosphotyrosine (pY) forms a high-affinity binding site that recruits and activates Src kinases via a dual interaction with their $\mathrm{SH} 2$ and $\mathrm{SH} 3$ domains [28]. The bound and activated Src kinase contributes substantially to the kinase activity associated with FAK or PYK2. Under most conditions, autophosphorylation can only proceed in trans, and it requires FAK/PYK2 dimerization and/or clustering [40-45]. However, in neurons, alternative splicing results in forms of FAK capable of autophosphorylation in cis, suggesting different regulatory modes in the brain [43]. 


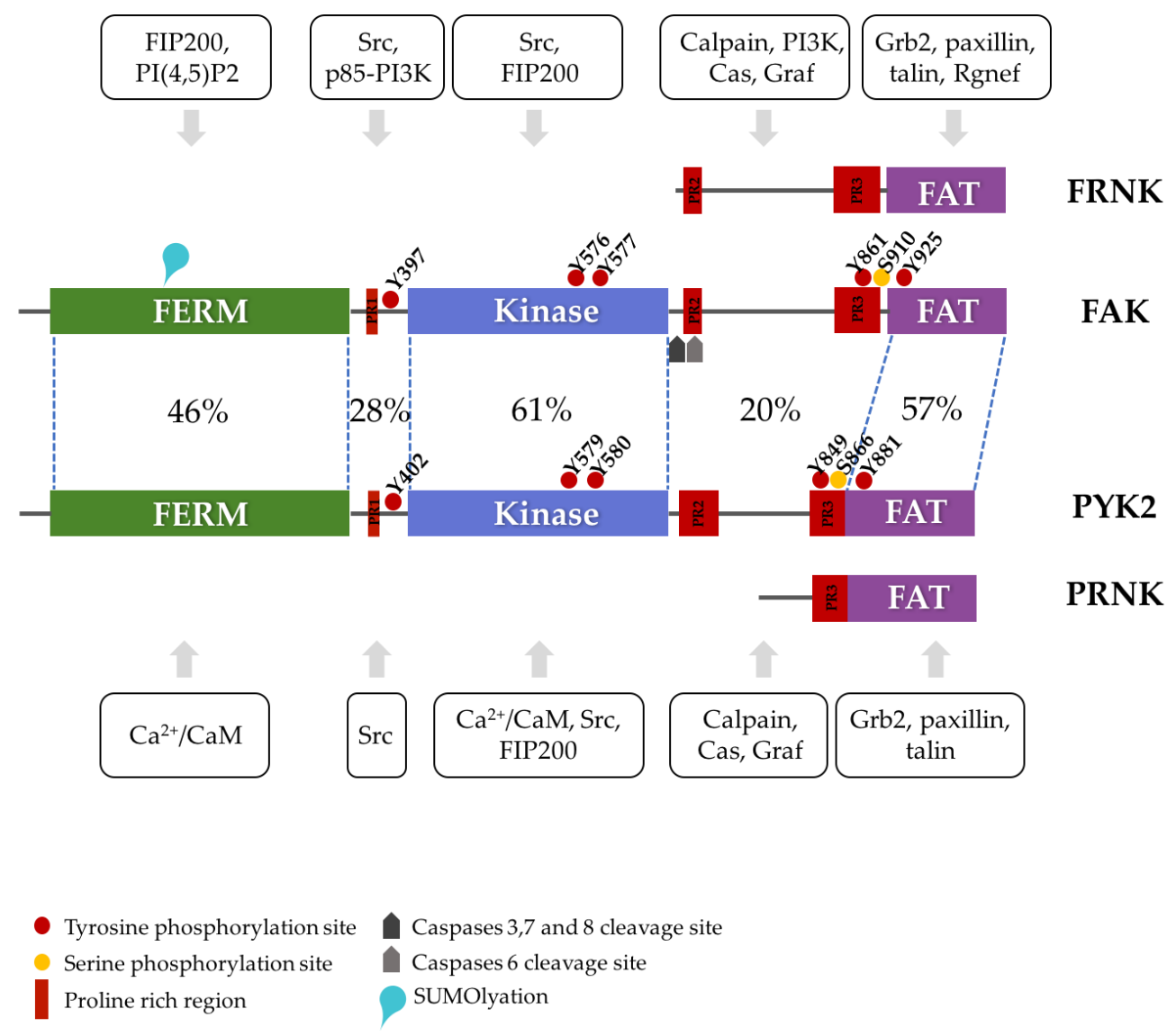

Figure 1. Schematic domain structure of focal adhesion kinase (FAK) and PYK2. The three folded domains are shown in green, blue and magenta. Interaction motifs, sites of post-translational modification, and examples of binding sites of proteins discussed in the text are shown. The percentages show the sequence identity between corresponding regions of FAK and PYK2. The alternatively transcribed products FRNK and PRNK are schematically represented with respect to FAK and PYK2. Interacting proteins for FAK or PYK2 are shown boxed either above (FAK) or below (PYK2) the schematic structure with arrows pointing at the interacting domain or linker region. For a more complete list of interacting partners, please see [26].

In FAK, dimers are formed through FERM:FERM and FERM:FAT interactions (Figure 2) [40]. In PYK2, FERM domains form crystallographic dimers that are identical to those formed by the FAK FERM domains (PDB 4eku), suggesting that the FERM:FERM dimerization mechanism might be conserved. Self-association of FAK and PYK2 is controlled by ligands. In FAK, trans-autophosphorylation, and thus kinase-dependent functions occur mostly at focal adhesions to which FAK is recruited, enriched and primed for dimerization via interactions between its FAT domain and the leucine-aspartic acid (LD) motifs of paxillin [40]. Additionally, clustering of FAK is promoted through interactions between the FERM domain and membrane-associated phospholipids [46]. Although the FAT domain in PYK2 can bind to paxillin [47], PYK2 is not as strongly localized as FAK is to focal adhesions in most cell types. Conceptually similar recruitment/clustering mechanisms appear to lead to activation of FAK and PYK2 at other transmembrane receptor complexes, such as T-cell immune synapses [48,49], or to activation of PYK2 in post-synaptic densities [50]. In addition, FAK and PYK2 play roles in various other cellular locations, including endosomes, adherens junctions, the microtubule organizing center and the nucleus [3,25]. Some of these functions (e.g., at nascent adhesions or in the nucleus) are kinase-independent. 


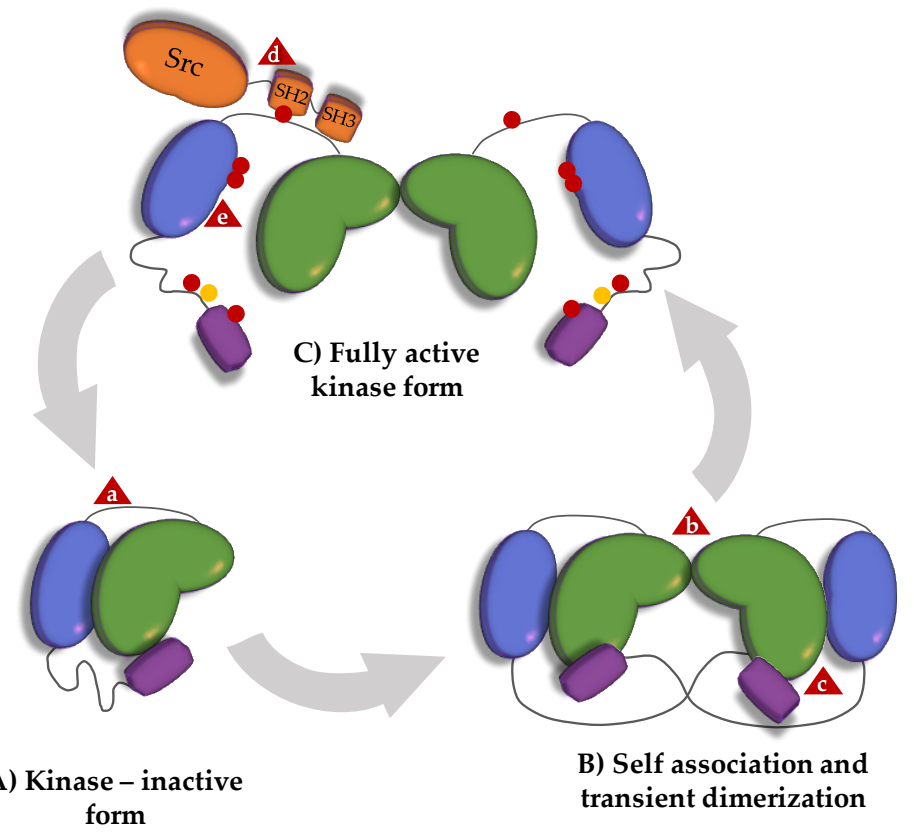

Figure 2. Canonical FAK activation scheme. (A) In the absence of integrin activation, an interaction between the FERM and kinase domain (indicated by a lower-case 'a' in a red triangle) inhibits FAK kinase activity. (B) Ligand-mediated recruitment and clustering of FAK at focal adhesions promotes transient dimerization by stabilizing weak FERM:FERM interactions (lower-case ' $b$ ' in a red triangle) and promoting FERM:FAT binding in trans (lower-case ' $c$ ' in a red triangle). (C) FAK clustering and self-association allows trans-autophosphorylation of Y397 (red dots) in the FERM-kinase linker. When phosphorylated, Y397 and PR1 form a bidentate binding site for the SH2 and SH3 domains of Src (lower-case ' $d$ ' in a red triangle). Recruitment-activated Src phosphorylates the activation loop of the FAK kinase domain (lower-case ' $\mathrm{e}$ ' in a red triangle) and other tyrosines on FAK, resulting in an open FAK conformation and full enzymatic activity. Triggered signaling may result in additional FAK modifications (e.g., serine phosphorylation; yellow dots) and may ultimately lead to dephosphorylation and/or displacement of FAK from focal adhesions (back to the closed monomeric inactive conformation of A), or to proteolytic cleavage and degradation (not shown in figure).

A major difference between FAK and PYK2 is that the latter can be activated by calcium ions $\left(\mathrm{Ca}^{2+}\right)$. The exact molecular mechanism for activation of PYK2 by $\mathrm{Ca}^{2+}$ remains unclear and controversial. The current view is that $\mathrm{Ca}^{2+}$ does not bind directly to PYK2, but binds through calmodulin (which has been reported to bind to either the FERM [45] or kinase domain of PYK2 [51] or through $\mathrm{Ca}^{2+}$-activated PYK2-modifying kinases (PKC, CaMKII, PKA), phosphatases (calcineurin, PP1) or Ca ${ }^{2+}$-activated proteins (PSD-95) [26,52].

In summary, FAK and PYK2 are versatile protein scaffolds with kinase-dependent and kinaseindependent functions. Although the details may differ, the underlying mechanism for the control and activation of kinase activity appears to be preserved between FAK and PYK2. Activation of the kinase function requires autophosphorylation. Cellular ligands can trigger trans-autophosphorylation by stabilizing a weak intrinsic propensity for self-association of FAK or PYK2 and/or by increasing the local protein concentration. Consequently, endogenous inhibitory mechanisms can prevent kinase activation by lowering FAK and/or PYK2 protein concentrations, by reinforcing inactivating autoinhibitory interactions, by competing with activating ligands, by dephosphorylating the Src-recruiting tyrosine or by displacing FAK/PYK2 from their sites of activation (Figure 1). 


\section{FRNK and PRNK}

Both the FAK and PYK2 genes (PTK2 and PTK2B, respectively) can produce shorter protein forms that lack the FERM and kinase domains [53,54]. These autonomously expressed non-cataytic C-terminal fragments presumably originate from alternative transcription initiation sites [55] and are called the FAK-related non-kinase (FRNK) and the PYK2-related non-kinase (PRNK). Starting at residues 693 and 780 of the canonical FAK and PYK2 isoforms, respectively, they include protein binding sites (proline-rich sites PR2 and PR3 for FRNK and PR3 for PRNK), phosphorylation sites (most prominently Y861 and S910 in FAK and Y849 and S866 in PYK2) and the FAT domain (Figure 1). PR2 and PR3 mediate the binding of different SH3-containing proteins, such as p130cas or Graf [54,56-60]. The FAT domain is sufficient to localize to focal adhesions, via interactions mainly with paxillin, but also with other protein ligands, such as talin or Rgnef/p190RhoGef [61-63]. Alternative interactions can also localize FAT to other structures, such as the T-cell receptor complex [48,64], or the growth cone of developing axons [65]. FRNK and PRNK maintain these functions, although without any regulatory influence from the other FAK/PYK2 regions. The production of these truncated forms has therefore been suggested to lead to a direct competition between FRNK or PRNK and FAK and/or PYK2 at sites that attract their FAT domains. Indeed, immunostaining showed that FRNK and PRNK localize to focal adhesions [53,54]. By competitively displacing FAK or PYK2, the alternative spliced variants lower the local concentrations of FAK and PYK2 and hence lower the propensity for trans-autophosphorylation of FAK and, possibly, PYK2. Accordingly, western-blot analysis indicates that FAK Y397 phosphorylation, the key step in FAK activation, decreases at increasing FRNK levels [66,67]. Moreover, by displacing FAK or PYK2 and by forming incomplete signaling complexes, FRNK and PRNK promote the disassembly of focal adhesions. Indeed, the expression of FRNK and PRNK correlates with focal adhesion turnover [53,54,68].

In addition to displacing FAK from common binding sites, FRNK may also act by directly binding to FAK. In rat aortic smooth muscle cells, FRNK co-immunoprecipitates with FAK [67]. This association is decreased by phosphorylation of FRNK S217 by the extracellular signal-regulated kinase (ERK1/2, henceforth referred to as simply ERK, unless stated otherwise) and increased by a factor of five by the S217A mutation. In cells, autophosphorylation of FAK was reduced by expression of FRNK, and even more so by expression of the S217A mutant form of FRNK [67]. The molecular basis for this phosphorylation-dependent interaction is unknown, but it might involve competition of FRNK with the intramolecular FERM:FAT interaction that promotes FAK for autophosphorylation by reinforcing FAK dimers. In size exclusion chromatography, dimerization of recombinant FAK was indeed weakened by the presence of recombinant FAT domains [40]. FRNK S217 corresponds to Erk-phosphorylated S910 in the canonical FAK isoform. This serine is situated five residues upstream of the four-helix FAT domain. The S910PPP motif weakly interacts with the FAT domain [69] and, when phosphorylated on S910, constitutes a proline-isomerase binding site $[67,70]$. Phopshorylation of FRNK S217 could therefore affect the FRNK:FAK association in various direct or indirect ways.

The possibility that a similar mechanism of competitive binding also exists for PRNK and PYK2 has not been tested. If this mechanism does exist, then this association would be regulated differently, because the PYK2 serine 866, which is also phosphorylated and located on the N-terminal side of its FAT domain, is not situated in an ERK phosphorylation motif [71].

\section{Proteases}

FAK and PYK2 are cleaved by several proteases. Some of the resulting fragments resemble FRNK or PRNK.

\subsection{Caspases}

Cysteine aspartate-specific proteases (caspases) play an important role in programed cell death (apoptosis). During apoptosis, caspases cleave critical repair and structural proteins that bolster cell survival. It has been shown that FAK is cleaved in the early stages of myc-induced apoptosis [72-74]. 
Sensitivity profiling of protease inhibitors showed that FAK is cleaved by caspase-3, 6, 7 and 8, with caspase-7 by far the most active [75,76]. Caspase- 3,7 and 8 generated $85 \mathrm{kDa}$ and $33 \mathrm{kDa}$ fragments [75,76]. Caspase-6 cleaved FAK with low efficiency, generating a $77 \mathrm{kDa}$ fragment [76]. Generated cleavage products and cleavage site consensus suggested that the 85-kDa cleavage happened after D772 and that the $77 \mathrm{kDa}$ cleavage occurred after D704 (Figure 1) [76]. Accordingly, the D772A mutation was not cleavable by caspase-3 [76]. It is expected that the separation from the FAT domain weakens the attachment of the FERM-kinase domain fragment to focal adhesions (and other FAT-targeted sites), leading to turnover of these structures. The $35 \mathrm{kDa}$ fragment generated from FAK cleavage resembles FRNK and may act similarly. Indeed, western-blot analysis indicated a decrease in FAK Y397 phosphorylation levels in HeLa cells transfected with the $35 \mathrm{kDa}$ fragment [76]. No direct evidence for caspase cleavage of PYK2 currently exists.

\subsection{Calpain}

Calpain, a calcium-dependent cysteine protease, cleaves both FAK and PYK2 [77,78]. When either purified calpain I or calpain II was added to FAK, four fragments were generated with sizes of $90 \mathrm{kDa}$, $50 \mathrm{kDa}, 40 \mathrm{kDa}$, and $35 \mathrm{kDa}$, and the cleavage was blocked by the calpain inhibitor, calpastatin [78]. Antibodies against the FAK kinase domain reacted with the 90-kDa and 50-kDa bands while antibodies against the C-terminus of FAK bound to the $35 \mathrm{kDa}$ band [78]. PYK2 cleavage products that were $80 \mathrm{kDa}$ and $75 \mathrm{kDa}$ in size were observed in human platelets; when treated with the calpain inhibitor calpeptin, the bands were no longer present [79].

\section{Regulation through Post-Translational Modifications}

In addition to irreversible protease cleavage, FAK and PYK2 are subjected to several types of post-translational modifications. FAK, but not PYK2, has been reported to be acetylated on residue A2 [71] and SUMOylated on K152 in the FERM domain [80]. SUMOylation was mediated by the SUMO ligase protein inhibitor of activated STAT1 (PIAS1) that interacted with FAK in cells and in vitro. SUMOylation was increased in suspended cells and correlated with increased nuclear presence of FAK and increased FAK Y397 phosphorylation independently of cell adhesion [80]. The mechanistic bases for this effect remain to be determined, but since K152 is in the vicinity of the FERM:kinase interaction site [31], its SUMOylation might interfere with the 'closed' autoinhibitory FAK conformation.

The most important post-translational modification is (de)phosphorylation [81]. According to the UniProt database, FAK and PYK2 are phosphorylated on serines ( 8 on FAK; 6 on PYK2), threonines (FAK: 2; PYK2: 2) and tyrosines (FAK: 8; PYK2: 8). Regulation through phosphorylation was previously reviewed in detail $[4,28,71,82]$. Here, we present a very broad overview. Tyrosine phosphorylation is generally associated with activating characteristics, starting of course with the autophosphorylation of the FERM-kinase linker tyrosine (Y397 and Y402 in FAK and PYK2, respectively). Src-mediated phosphorylation of a tyrosine in the first FAT helix (FAK-Y925 and PYK2-Y881) triggers activation of mitogen-activated protein (MAP) kinases via the phosphotyrosine-binding adapter protein Grb2 [83-86]. In FAK, phosphorylation of S910 by ERK recruits the proline-isomerase PIN1 and subsequently the protein tyrosine phosphatase (PTP-PEST), which then counteracts FAK phosphorylation and activation, thus closing a negative feedback loop [70,87]. In PYK2, a nuclear export signal in its kinase-FAT linker is activated by phosphorylation of S778 by protein kinase A (PKA) and deactivated by the phosphatase calcineurin [34]. Conversely, PKC-mediated phosphorylation of FAK on S722 promoted nuclear localization [88]. (De)phosphorylation therefore regulates nuclear localization of PYK2 and FAK, although via different mechanisms. Phosphorylation can also alter the protein structure, as seen in FAK activation loop tyrosines. Their phosphorylation not only increases the kinase catalytic activity by restructuring the activation loop, but it also prevents the kinase domain from forming an inhibitory interaction with the FERM domain [31].

While most kinases or phosphatases probably form only transient or short-lived complexes with FAK and/or PYK2, the tyrosine-kinases Src and Fyn durably attach to the Y397-phosphorylated FERM-kinase linker. The resulting protein complexes are associated with a catalytically active state $[4,28,89-91]$. 
In the following, we highlight one other kinase and one phosphatase that also have lasting associations with FAK or PYK2 and exhibit inhibitory effects.

\subsection{Liver Kinase $\beta 1$ (LKB1)}

The liver kinase $\beta 1$ (LKB1) or STK11 is a multifunctional serine/threonine kinase that links energy sensing and cell polarity [92-94]. In particular, LKB1 stabilizes cell polarity under energy stress. Given that loss of cell polarity increases undirectional 'exploratory' migration, LKB1 controls cell movements during embryogenesis and wound healing [92-94]. LKB1 also counteracts cancer cell metastasis and is the third most frequently mutated gene in lung adenocarcinoma [95-97]. Rather than through phosphorylation of its activation loop, LKB1 (Figure 3) is activated allosterically through an association with the pseudo-kinase STRAD $\alpha$, which is tethered to LKB1 by the scaffolding protein MO25 $\alpha$ [98]. In addition, LKB1 activity and localization are affected by post-translational modification $[92,94]$. SUMOlyation of LKB1 K178, in response to energy stress, promotes the interaction between LKB1 and the AMP-activated protein kinase (AMPK). The resulting phosphorylation and activation of AMPK help to maintain the energy balance in a cell during energy stress [99]. Furthermore, live cell imaging experiments show that farnesylation on C430 within the LKB1 C-terminus is required for its co-localization with actin at the leading edges of migrating cells. The LKB1 kinase activity is required to stabilize the actin colocalization of LKB1 and to promote mesenchymal polarization and directed cell migration $[93,94]$.

Initially, LKB1 was linked to FAK through the observation that the FAK adhesion pathway is upregulated in $\mathrm{LKB1}^{-/-}$mice in a mutant Kirsten rat sarcoma (KRAS) background [100]. Subsequent analyses confirmed that the presence and activation of LKB1 represses phosphorylation of FAK Y397, Y861 and Y925 [93,101]. The current model proposes that farnesylation colocalizes LKB1 with actin at the leading cell edge of migratory cells, where the LKB1 kinase activity indirectly decreases FAK activation. Inactivation of FAK decreases focal-adhesion turnover and hence stabilizes focal adhesions at the leading edge. Conversely, loss of LKB1 farnesylation or kinase activity results in FAK hyperphosphorylation and leads to cells that present exploratory behaviors with loss of directional persistance [92,93].

The exact mechanisms by which LKB1 negatively affects FAK activation are unclear. FAK and LKB1 can co-immunoprecipitate each other, suggesting that they colocalize within the same protein complex. However, purified FAK and LKB1/MO25 $\alpha /$ STRAD $\alpha$ proteins did not interact in vitro, suggesting that the interaction between FAK and LKB1 may not be direct [93]. One possibility would be that the effect of LKB1 is mediated by its downstream substrates. Activation of AMPK or its family members (e.g., MARK1 and MARK4) correlates with inhibition of FAK phosphorylation in several systems, including human liver cancer cell lines and muscle cells [101-104]. The details of these inhibitory pathways through AMPK or MARKs remain incompletely established. Intriguingly, one study could recapitulate the FAK pY397-suppressing effect of LKB1 by expressing just the LKB1 N-terminal arm region (residues 1-47) in LKB1-null H157 cells, suggesting that, at least in this setting, LKB1 kinase activity was not needed [93]. The possibility of an interaction between PYK2 and LKB1 has not yet been explored, although PYK2 activation has been observed following AMPK activation in muscle cells $[105,106]$.

\subsection{PTEN}

The phosphatase and tensin homolog deleted on chromosome 10 (PTEN) (Figure 3) exerts a dual function as both a lipid and a protein phosphatase $[107,108]$. As a lipid phosphatase, PTEN converts phosphoinositide $(3,4,5) \mathrm{P} 3$ to phosphoinositide $(4,5) \mathrm{P} 2$, and is therefore the antagonist of the phosphoinositide-3 kinase (PI3K). PI3K directly associates with FAK through its PR motifs [109] promoting cell survival via the activation of the PI3K/Akt pathway. This association has an important effect on maintaining cell adhesion to integrins, which is, in some tissues like endothelial cells, indispensable for cell survival [110]. 
PTEN affects cell migration and invasiveness by dampening this FAK/PI3K pathway. The most commonly observed effect of PTEN on FAK might be indirect through its lipid-phosphatase-based downregulation of the PI3K pathway [111]. As an additional indirect mechanism, PTEN was shown to inhibit FAK expression levels in myeloma and gastric cancers [112,113]. However, PTEN can also form a complex with Y397-phosphorylated FAK in glioma, breast cancer and colon carcinoma cells [114,115]. This interaction leads to dephosphoryation of pY397 following cell detachment in these cells. The FAK:PTEN association was compatible with the FAK:paxillin association, but it competed with binding of PI3K and Src to FAK [114,115]. Both the p85 subunit of the PI3K and the SH2-SH3 fragment of Src kinase bind to the Y397-phosphorylated FERM-linker fragment $[4,28,89,90,116,117]$, suggesting that PTEN binding involves the same region. Moreover, it has been observed that FAK phosphorylates PTEN at Y336 with a positive effect on PTEN stability and phosphatase activity $[118,119]$. Y336 is located in the phospholipid-binding region of the $\mathrm{C} 2$ domain (Figure 3). In principle, the introduction of a negative charge in this position is expected to hamper association with negatively charged lipid headgroups. Future research is needed to clarify the underlying molecular mechanisms causing the multiple effects of the FAK:PTEN association.
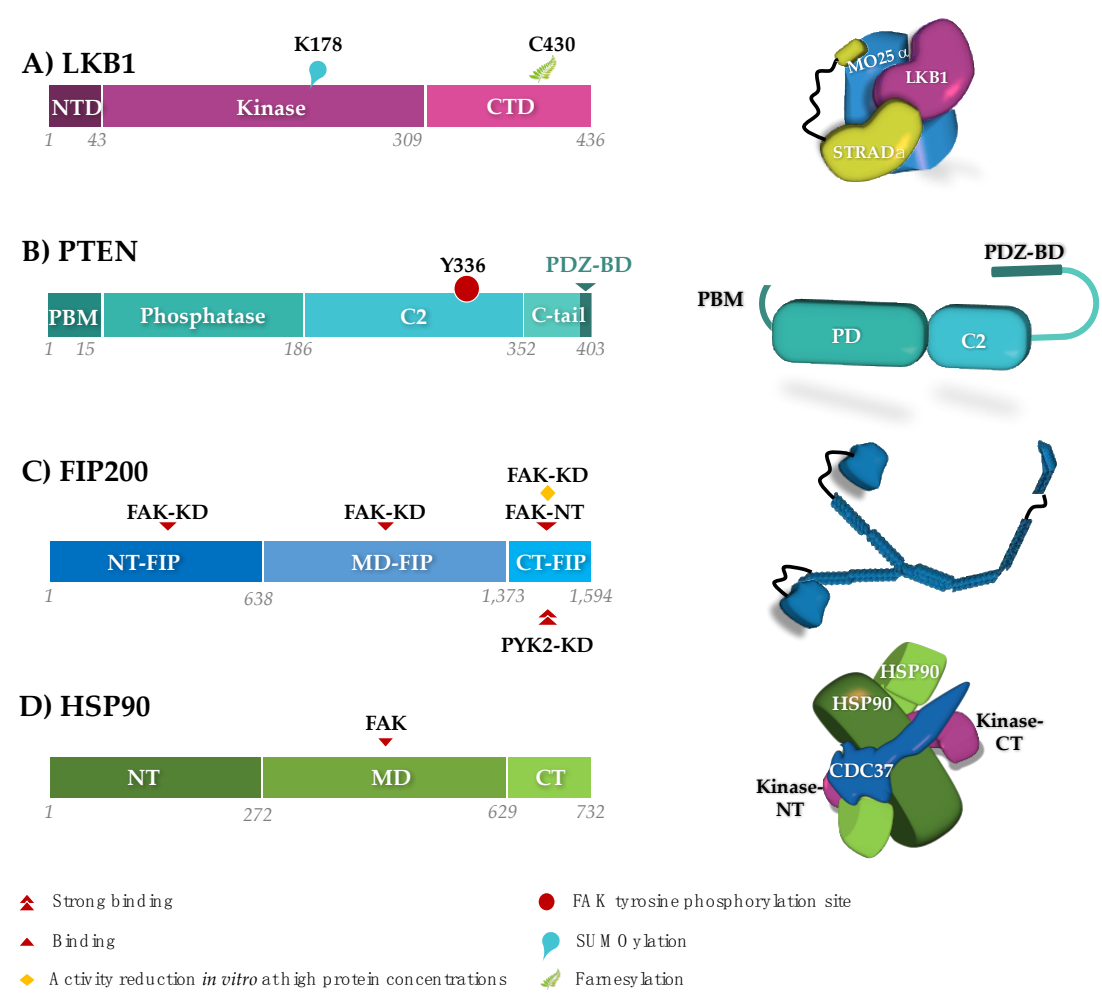

Figure 3. Schematic domain structures (left) and three-dimensional (3D) architectures (right) of protein regulators of FAK:LKB1, PTEN and FIP200 are negative regulators. LKB1 is shown as part of the activating complex formed with MO25 $\alpha$ and STRAD $\alpha$ (according to PDB accession $2 w t k$ ). The presented 3D structure of FIP200 (blue) is highly speculative and based on secondary structure predictions and homology modeling. The stabilizing function of HSP90 is upregulated in cancers. HSP90 is displayed with the kinase-specific adaptor CDC37, maintaining the separated N-terminal (NT) and C-terminal (CT) lobe of a kinase domain (taken from PDB $5 \mathrm{fwl}$ ). Binding sites and post-transcriptional modifications relevant to their interaction with FAK and PYK2 are indicated. Abbreviations are: (A) LKB1:NTD, N-terminal domain; CTD, C-terminal domain. (B) PTEN:PD, phosphatase domain; PBM, PI(4,5)P2-binding module; PDZ-BD: PDZ binding domain. (C/D) FIP200/HSP90:NT, N-terminal domain; MD: middle domain; CT, C-terminal domain. FAK:KD, kinase domain; NT, N-terminal fragment. 


\section{Regulation through Non-Catalytic Protein Interactions}

FAK or PYK2 also have a large number of interaction partners that do not post-translationally modify them. Many of these partners either control subcellular localization, or attach to FAK or PYK2 to form active signaling complexes $[4,28,117]$. So far, to our knowledge, only one non-catalytic protein has been identified as an inhibitor of FAK and PYK2 activation, namely FIP200.

\section{RB1CC1/FIP200}

In vitro and in vivo protein interaction assays led to the discovery of a $200 \mathrm{kDa}$ interacting protein for both FAK and PYK2, named the FAK family kinase-interacting protein (FIP200) [120]. The 1594 residue FIP200 is predicted to contain an N-terminal ubiquitin-like domain (ULD) but would otherwise be mostly composed of loops and long helices, possibly forming coiled-coiled structural elements [120,121] (Figure 3). Accordingly, FIP200, also known as the RB1-inducible coiled-coil protein 1 (RB1CC1), is a non-catalytic scaffolding protein. It regulates a wide range of cellular events, such as growth, proliferation, apoptosis and autophagy, through interactions with signaling proteins (e.g., PYK2, FAK, ActA, p53, TSC1, ASK1, TRAF2 and Stathmin) [122].

Immunofluorescence analyses of FIP200 indicated a mostly diffused localization in the cytoplasm [120]. But the presence of a consensus nuclear localization signal implies an alternative function for FIP200 in the nucleus, where it may act as a transcription factor [120,121,123,124]. Additionally, FIP200 polyclonal antibody pull-downs revealed a partial colocalization of the protein in focal contacts where it may regulate FAK and vinculin [125]. FIP200 binding decreases the kinase activity of FAK and PYK2 [120,125] and the autophosphorylation levels of FAK [125]. During cell adhesion to fibronectin, FAK activation correlates with increased dissociation of FAK and FIP200 [122,125].

Given that FIP200 inhibits both FAK and PYK2, which can have opposing functions, for example in the promotion of the cell cycle and apoptosis, the outcome of their inhibition by FIP200 may be cell-type specific. For example, overexpression of FIP200 in glioblastoma cells (where PYK2 has dominant functions) leads to inhibition of apoptosis [126], whereas in breast cancer cells, FIP200 acts as a tumor suppressor gene [124].

Although the direct interaction with FIP200 appears to inhibit both FAK and PYK2 in a similar manner, the way in which FIP200 physically binds them might differ (Figure 3). In one study, the FIP C-terminal (CT-FIP; residues 1374-1591) interacts strongly with the PYK2 kinase domain. However, CT-FIP only binds to the N-terminal region of FAK, while the FAK kinase domain (residues 403-672) binds to the FIP200 N-terminus (NT-FIP; residues 1-638) and the middle domain (MD-FIP; residues 639-1373) [125]. Conversely, NT-FIP and MD-FIP did not show affinity for PYK2. The apparent differences might be caused by a change in the relative affinity of the fragments of FIP200 for FAK or PYK2. For example, although CT-FIP did not display significant binding to the FAK kinase, it could reduce its enzymatic activity when present at high concentrations in in vitro kinase assays $[125,126]$. The differences in binding affinity might have important functional implications in cases where FAK and PYK2 are present, but these functions might be different. For example, in retinoblastoma cells, the interaction of CT-FIP with PYK2 is stronger, and hence preferred, than the interaction of the other two domains of FIP200 with FAK [120,125,126].

\section{Chaperones}

Molecular chaperones can interact with exposed hydrophobic patches of misfolded proteins and help them to (re)establish their native and functional three-dimensional structure. While chaperones commonly release refolded clients, some remain associated with structurally fragile proteins to sustain their function. Thus, chaperones maintain cellular proteins in their functional state and prevent their degradation $[127,128]$. Overexpression of chaperones, in particular of inducible heat shock proteins (HSPs), is prevalent in cancer cells where proteotoxic stress is endemic $[129,130]$. The resulting increase in protein stablity and function may enhance the action of overexpressed and/or mutated oncogenes 
and more generally help to create a protective and resistant cytoplasmic environment [131]. Inversely, a decrease in the expression of molecular chaperones is associated with accumulation of misfolded proteins and the onset of neurodegenerative diseases [131].

In a systematic survey of the kinome, FAK and PYK2 were identified as 'weak clients' for HSP90 and its kinase-specific cochaperone, CDC37 [128]. Xiong et al. (2014) reported an interaction between HSP90 $\beta$ and FAK in breast cancer cells [132]. FAK bound to the middle domain of HSP90 $\beta$ (residues 233-620), in agreement with a structural analysis of the complex formed by HSP90, CDC37 and a client cyclin-dependent kinase (CDK4) [133]. The HSP90 $\beta$ interaction protects FAK from ubiquitylation-dependent proteasomal degradation. Inhibition of both HSP90 $\beta$ and FAK reduces tumor growth in breast cancer cells [132].

Chaperones can also have more indirect effects on FAK activity. Caino et al. showed that inhibition of mitochondrial HSP90 chaperones, including the tumor necrosis factor receptor-associated protein-1 (TRAP-1), leads to a stress-triggered activation of the LKB1-AMPK pathway [134]. AMPK phosphorylates and activates Unc-51-like autophagy activating kinase (ULK1), which in turn phosphorylates FIP200. These events activate the autophagy-initiating complex between ULK1, FIP200 and autophagy-related protein 13 (atg13), and they allow activated FIP200 to maintain FAK in an inactive unphosphorylated state [134]. Increased expression and increased function of mitochondrial HSP90, as observed in some cancers, lead to sufficient ATP production in nutrient-scarce tumor cells to avoid triggering activation of the LKB1-AMPK pathway. This releases the inhibitory effect of FIP200 on FAK, results in increased cytoskeletal dynamics and enhances invasion of tumor cells into bone or liver in mice disease models [134].

Additionally, heat shock proteins HSP70 and Mamalian relative DNA J (MRJ, also named DNAJB6) exert an oncogenic effect on colon cancer cells. HSP70 and MRJ interact with the urokinase-type plasminogen activator receptor (uPAR) to activate FAK, c-Src, H-Ras, AKT and MAPK cell-signaling pathways, regulating cell adhesion and migration [135]. Another example is the molecular chaperone Cosmc. Cosmc is necessary for the formation of active T-synthase, which catalyses the production of $\mathrm{T}$ antigen. Increased expression of $\mathrm{T}$ antigen is correlated with tumor metastasis and poor prognosis in colorectal cancer. The forced expression of Cosmc in colon cancer cell lines increases $\mathrm{T}$ antigen expression, resulting in increased activation of the FAK, PI3K/Akt and MAPK kinase (MEK)/ERK signaling pathways [136]. Cosmc-induced tumor cell migration and invasion suggest that Cosmc may serve as a potential target for colorectal cancer. The eaxct mechanisms that lead to FAK Y397 phopshorylation through either HSP70/MRJ or Cosmc under these conditions have not yet been determined. Given that FAK activation involves the PI3K and MAPK pathways in both cases, the molecular routes may be overlapping or converging.

\section{Transcriptional Regulation of FAK and PYK2}

The normal or alternative intronic promoters of the PTK2 and PTK2B genes are controlled in a tissue- and developmental-stage-dependent manner [55]. Factors that activate the PTK2 promoter include the nuclear factor-кB (NF-кB), argonaute 2 (AGO2), PEA3 and NANOG [15,137-139]. Overactivity of these PTK2 transcription factors is associated with tumorigenesis, and their silencing can block tumorigenesis and metastasis [10]. The major reppressor of the human PTK2 and PTK2B promoters is the stress-induced tumor suppressor p53 [140-142]. Two putative binding sites for p53 have been indentified in the PTK2 promoter [143]. In turn, nuclear FAK promotes degradation of p53 by linking it to the E3 ubiquitin ligase Mdm2, using the FERM domain as a scaffold. FERM-triggered proteosomal degradation of p53 leads to cell proliferation and survival under cellular stress [35]. A strong correlation between FAK overexpression and p53 mutations has been observed in human breast cancer [144]. While loss or damage of p53 is closely associated with the development of tumors, forced overexpression can cause premature aging [145]. However, therapeutic restoration of a functional p53 pool at endogenous levels can have tumor-suppressive effects [146]. 


\section{Non-Coding RNA}

Non-coding RNA (ncRNA) are RNA molecules that are not translated into proteins [147]. ncRNAs include transfer RNA (tRNA), ribosomal RNA (rRNA) and small RNAs. ncRNAs are further classified according to their length and function, and they include long non-coding RNA (lncRNA), micro-RNA (miRNA), small-interfering RNA (siRNA) and piwi-interacting RNA (piRNA). Small RNAs can regulate gene expression at the transcriptional and post-transcriptional level, but they can also affect protein function through direct binding and scaffolding. Many ncRNAs are abnormally expressed in cancer, leading to large-scale deregulation of protein genes, most prominently the tumor suppressor p53 [148]. Here, we focus on those ncRNAs that directly alter expression and function of FAK or PYK2; we note that many other ncRNAs have pleiotropic effects that may also affect FAK or PYK2.

\section{1. microRNA}

miRNAs contain about 20 nucleotides and are transcribed from miRNA genes or coding gene introns. miRNAs post-transcriptionally downregulate target genes by either destabilizing and degrading their mRNA or by binding to the $3^{\prime}$-untranslated region ( $\left.3^{\prime} \mathrm{UTR}\right)$ of their mRNA, thus inhibiting translation $[149,150]$. miRNAs are implicated in various cellular processes, such as development, cell proliferation, and differentiation. They also regulate junction protein gene expression and extracellular matrix —associated processes, thus helping to maintain the integrity of the cellular structure [151,152]. By inhibiting gene translation, many miRNAs act as tumor suppressors and their downregulation in cancer cells generally promotes cancer formation and metastasis [153]. Conversely, forced upregulation of miRNA can have tumor-suppressive effects, making miRNAs interesting therapeutic targets and prognostic markers for anti-cancer therapy.

\subsubsection{Tumor-Suppressor miRNAs Acting Directly on FAK}

miR-7. One of the most studied microRNAs regulating FAK is miRNA-7 (miR-7). miR-7 is encoded by three DNA loci (9q21, 15q26 and 19q13) that produce the same mature 23-nucleotide miR-7 sequence. miR-7 is enriched in various normal tissues and implicated in organ development and other biological processes (reviewed by [154]). miR-7 can directly bind to $3^{\prime}$ UTR of FAK mRNA, repressing FAK protein expression [155]. miR-7 is also involved in the growth, migration, and invasion of many cancer types. miR-7 downregulates glioblastoma and colon cancer cell invasiveness by repressing FAK protein expression $[155,156]$. Forced expression of miR-7 significantly reduces endogenous FAK protein expression in breast cancer cell lines, inhibits primary breast tumor growth and invasiveness, and represses metastatic migration of breast cancer xenografts [157]. In non-small-cell lung carcinoma (NSCLC) cells, miR-7 suppresses cell proliferation, migration and invasion by downregulating FAK expression and inhibiting the activation of the ERK/MAPK signaling pathway [158]. The inverse relation between miR-7 expression and tumor growth and invasiveness suggests that miR-7 can be used as a diagnostic marker for certain cancers [154]. miR-7 also positively affects radiation therapy outcomes as it increases cancer cell radio-sensitivity [159], phenocopying an effect observed for FAK-targeting inhibitors [160-162].

miR-1298. miR-1298 has been identified in a global miRNA functional screen as selectively lethal to cells expressing mutated KRAS, which is an oncogene mutated in $20 \%$ of human cancers, mainly NSCLC and colorectal cancers. miR-1298 acts a tumor suppressor in KRAS-driven NSCLC and colorectal cancer cells by directly targeting the mRNA of both FAK and the Laminin subunit beta 3 (LAMB3), lowering their protein expression levels [163]. Interestingly, expression of only LAMB3, and not FAK, is upregulated by KRAS; yet silencing of either FAK or LAMB3 recapitulates miR-1298-induced cell death in KRAS-dependent cancer cells. However, FAK Y925 phosphorylation also links FAK activation via Grb2 to activation of the RAS pathway [164], and FAK signaling is a requirement for the maintenance of KRAS-dependent adenocarcinomas [165]. 
miR-543. miR-543 expression is decreased in tumorous endometrium tissue and associated with impaired cancer cell invasion in vitro. miR-543 binds to the 3'UTR of FAK and of the TWIST1 oncogene, decreasing their expression at both the mRNA and protein levels. This repression results in impaired tumor cell proliferation, migration and invasion in cancer cell lines [166].

miR-379-5p. Underexpression of miR-379-5p in hepatocellular carcinoma (HCC) is correlated with the tumor node-metastasis (TNM) stage and metastasis. miR-397-5p inhibits tumor migration and invasion in HCC cells by direct binding to the $3^{\prime} \mathrm{UTR}$ of FAK, inhibiting FAK translation while the mRNA level is not affected. This inhibition suppresses AKT activation and hence inhibits the PI3K/AKT pathway. Introduction of miR-397-5p represses HCC metastasis and EMT in vivo [167].

miR-193b. A recent study showed that miR-193b is downregulated in liposarcoma while its reintroduction induces apoptosis in liposarcoma cells. miR-193b functions by directly targeting FAK mRNA and regulating the oncogenic FAK/SRC/BCAR1 signaling pathway [168].

\subsection{2. miRNAs Indirectly Regulating FAK}

Rather than directly suppressing FAK expression by binding to FAK mRNA, miRNAs can indirectly affect FAK targeting by activating upstream effectors. For instance, miR-205 and miR-940 negatively regulate Src kinase expression. miR-205 is suppressed in renal and prostate cancer. Its inhibition increases cell adhesion in normal keratinocytes, whereas its overexpression reduces tumor growth in vivo [169-171]. miR-205 binds to Src 3'UTR, degrading its mRNA, decreasing Src protein expression and hence activating FAK and paxillin [169-171]. The exosomal miR-940 also inhibits the expression of Src at the mRNA and protein levels in ovarian cancer, thus decreasing the activation of downstream proteins such as FAK, paxillin and Akt [172].

\subsubsection{Oncogenic miRNAs Acting on FAK}

Although most FAK-targeting miRNAs act as tumor suppressors by lowering FAK expression and/or activation, some miRNAs show oncogenic effects by targeting cellular inhibitors of FAK [173,174]. The miR-130 family (miR-130b, miR-301a and miR-301b) is one example that is upregulated in bladder cancer tissues. The miR-130 family activates FAK and the Akt signaling pathway by targeting PTEN either directly through binding to its mRNA (miR-130b) or indirectly by repressing PTEN expression (miR-301a/b). High expression of miR-130 increases migration and invasion of bladder cancer cells [173] and the progression of malignant melanoma [174].

Several other miRNAs have been found to influence the activation of FAK by repressing or activating an upstream effector of FAK. Due to space limitations, these miRNAs are listed in Table 1 but not discussed further.

Table 1. microRNAs with indirect effects on (FAK).

\begin{tabular}{|c|c|c|c|c|}
\hline miRNA & Cell Type & Target Site(s) & Role & Ref. \\
\hline miR-9 & Ovarian serous carcinoma & TLN1, FAK, Akt & Tumor suppressor & [175] \\
\hline miR-16 & Glioma & $\begin{array}{l}\mathrm{p}-\mathrm{FAK} \text {, } \mathrm{p} \text {-Akt expression, nuclear } \\
\text { factor- } \mathrm{kB} \text {, Slug }\end{array}$ & Tumor suppressor & [176] \\
\hline miR-17-3p & Cardiac fibroblasts & $\begin{array}{l}\text { Par4, CEBPB, FAK, N-cadherin, } \\
\text { vimentin, Oct4, Sca-1, E-cadherin }\end{array}$ & Oncogene & [177] \\
\hline miR-21 & $\begin{array}{l}\text { Breast cancer lymph node } \\
\text { metastasis }\end{array}$ & CDK5RAP1, CDK5 activator p39, FAK & Oncogene & [178] \\
\hline miR-34a & Neuroblastoma, colorectal cancer & VEGF, FAK & Tumor suppressor & {$[179,180]$} \\
\hline miR-92b & $\begin{array}{l}\text { Esophageal squamous } \\
\text { cell carcinoma }\end{array}$ & ITGAV, FAK, Rac1 & Tumor suppressor & [181] \\
\hline miR-124 & Glioma & $\begin{array}{l}\text { Capn4, -FAK, MMP2, vimentin, } \\
\text { N-cadherin }\end{array}$ & Tumor suppressor & [182] \\
\hline miR-130a & Hemangioma & TFPI2, FAK, PI3K, Rac1, mdm2 & Oncogene & [183] \\
\hline miR-133b & Osteosarcoma & $\begin{array}{l}\text { BCL2L2, MCL-1, IGF1R, MET, } \\
\text { FAK, Akt }\end{array}$ & Tumor suppressor & [184] \\
\hline
\end{tabular}


Table 1. Cont.

\begin{tabular}{|c|c|c|c|c|}
\hline miRNA & Cell Type & Target Site(s) & Role & Ref. \\
\hline $\operatorname{miR}-134$ & Hepatocellular carcinoma & ITGB1, FAK and RhoA & Tumor suppressor & [185] \\
\hline miR-138 & $\begin{array}{l}\text { Ewing's sarcoma, head and neck } \\
\text { squamous cell carcinoma }\end{array}$ & RhoC, FAK, Src, Erk(1/2) & Tumor suppressor & [186-190] \\
\hline miR-141 & Renal cell carcinoma & EphA2, p-FAK, p-AKT, MMP2/9 & Tumor suppressor & [191] \\
\hline miR-141/200c cluster & Breast cancer & VEGF-A, FAK, PI3K, Akt & Oncogene & [192] \\
\hline miR-145 & Glioma & CTGF, SPARC, FAK & Tumor suppressor & [193] \\
\hline $\operatorname{miR}-150$ & Lung cancer & Src, FAK, Ras, ERK & Oncogene & [194] \\
\hline miR-151-5p & $\begin{array}{l}\text { Gastric cancer, } \\
\text { hepatocellular carcinoma }\end{array}$ & $\begin{array}{l}\text { FAK (host genet), RhoGDIA, Rac1, } \\
\text { Cdc42, Rho GTPases }\end{array}$ & Oncogene & [195-197] \\
\hline $\operatorname{miR}-187$ & Ovarian cancer & Dab2, E-cadherin, vimentin, FAK & Tumor suppressor & [198] \\
\hline miR-199a-5p & Breast cancer & Ets-1, FAK/Src/Akt/mTOR & Tumor suppressor & [199] \\
\hline miR-202 & $\begin{array}{l}\text { Esophageal squamous } \\
\text { cell carcinoma }\end{array}$ & LAMA1, FAK-PI3K-Akt & Tumor suppressor & [200] \\
\hline $\mathrm{miR}-221$ and $\mathrm{miR}-26 \mathrm{~b}$ & Mesenchymal stem cells & PTEN, FAK, PI3K, Akt & & [201] \\
\hline miR-296-3p & Lung Adenocarcinoma & PRKCA, FAK-Ras-c-Myc & Tumor suppressor & [202] \\
\hline $\operatorname{miR}-375$ & Mesenchymal stem cells & FAK, paxillin, PDK1, Akt & & [203] \\
\hline $\operatorname{miR}-383$ & Glioma & VEGF/VEGFR2, FAK, Src & Tumor suppressor & [204] \\
\hline miR-425-5p & Hepatocellular carcinoma & $\begin{array}{l}\text { SCAI, integrin } \\
\beta 1-F a k / \text { Src-RhoA/CDC42, } \\
\text { PTEN-AKT, TIMP2-MMP2/MMP9 }\end{array}$ & Oncogene & [205] \\
\hline miR-491-5p & Oral squamous cell carcinoma & $\begin{array}{l}\text { GIT1, paxillin, FAK, EGF/EGFR- } \\
\text { ERK1/2, MMP2/9 }\end{array}$ & Tumor suppressor & [206] \\
\hline miR-542-3p & Colon cancer & ILK, FAK/c-Src & Tumor suppressor & [207] \\
\hline $\operatorname{miR}-647$ & Gastric cancer & $\begin{array}{l}\text { ANK2, FAK, MMP2, MMP12, } \\
\text { CD44, SNAIL1, }\end{array}$ & Tumor suppressor & {$[208,209]$} \\
\hline miR-708 & Metastatic breast cancer & Neuronatin, ERK, FAK & Tumor suppressor & [210] \\
\hline
\end{tabular}

\subsection{4. miRNA Regulators of PYK2}

Not many miRNAs are known to regulate the expression of PYK2. However, PYK2 is a direct target of miRNA-23b, which binds to its 515-522 3'UTR. Overexpression of miR-23b decreases the protein level of PYK2, but not of FAK, and results in reduced cell proliferation, migration and invasion of hepatocellular carcinoma and glioblastoma cells. Additionally, elevated expression of miR-517a and miR-517c result in decreased PYK2 expression, suggesting that these miRNAs play a tumor-suppressor role in hepatocellular carcinoma [211].

\subsection{LncRNAs}

NcRNAs with more than 200 nucleotides, commonly called lncRNAs, are implicated in many biological and pathological processes [212]. The oncogenic lncRNA metastasis-associated lung adenocarcinoma transcript 1 (MALAT1) promotes vasculogenic mimicry and angiogenesis by increasing the expression of VE-cadherin and b-catenin on cell membranes, as well as by increasing levels of metalloproteases MMP2/9 and MT1-MMP and of phosphorylated ERK, FAK, and paxillin. These events promote gastric cancer tumor growth and metastasis [213]. LncRNA H19 is a competing endogenous RNA (ceRNA) for miR-138. Given that miR-138 targets FAK and suppresses its expression, the action of lncRNA H19 increases FAK expression and osteogenesis of bone marrow mesenchymal stem cells under tension [189]. LncRNA can also act by directly binding to proteins. Upregulation of the lncRNA CASC9 in esophageal squamous cell carcinoma (ESCC) was correlated with metastasis and poor prognosis. CASC 9 upregulates the laminin subunit LAMC2 by recruiting the transcriptional coactivator CREB-binding protein (CBP) to the LAMC2 promoter. LAMC2 upregulation is associated with phosphorylation of FAK and activation of the PI3K/AKT pathway [214]. Phenotypically, CASC9 therefore produces opposing effects to those of miR-1298 (see above). 


\section{Discussion}

By linking cell motility and survival, FAK and PYK2 promote the survival and invasiveness of cancer cells. In particular FAK, but also to some extent PYK2, have been recognized as anti-cancer targets. Small-molecule inhibitors that target FAK and PYK2 are currently in clinical trials. However, the efficacy and specificity of these inhibitors remain low in several cases, and their exact mechanism of action is not always well understood [10,215]. Moreover, the application of anti-cancer drugs designed to selectively inhibit single kinases can trigger large-scale signal network rewiring, leading to bypass mechanisms that render the drug ineffective [216,217].

Stringent endogenous control of kinase activity is essential for normal cellular function and homeostasis. Evoking naturally evolved endogenous control mechanisms for therapeutic purposes may trigger fewer escape maneuvers in diseased cells than are currently allowed by targeted kinase inhibitors. Endogenous mechanisms that (negatively) regulate the activity of FAK and PYK2 in normal or diseased cells might inspire improved or additional therapeutic interventions (Figure 2).

FAK and PYK2 play numerous kinase-dependent and kinase-independent biological roles (Figure 4) that can vary with cellular status, cell type and subcellular location. While playing these roles, FAK and PYK2 can have opposing, redundant or synergistic effects, depending on the cell type and condition. In response, cells use different general or specifically adapted mechanisms to control FAK and/or PYK2. The general mechanisms involve chaperones, proteases, and kinases/phosphatases (such as the Src, LKB1 or PTEN). Therapeutic strategies that target these regulatory mechanisms will likely provoke pleiotropic effects, which might not always be counterproductive in diseased cells, but would generally be difficult to predict and may adversely affect healthy tissue.

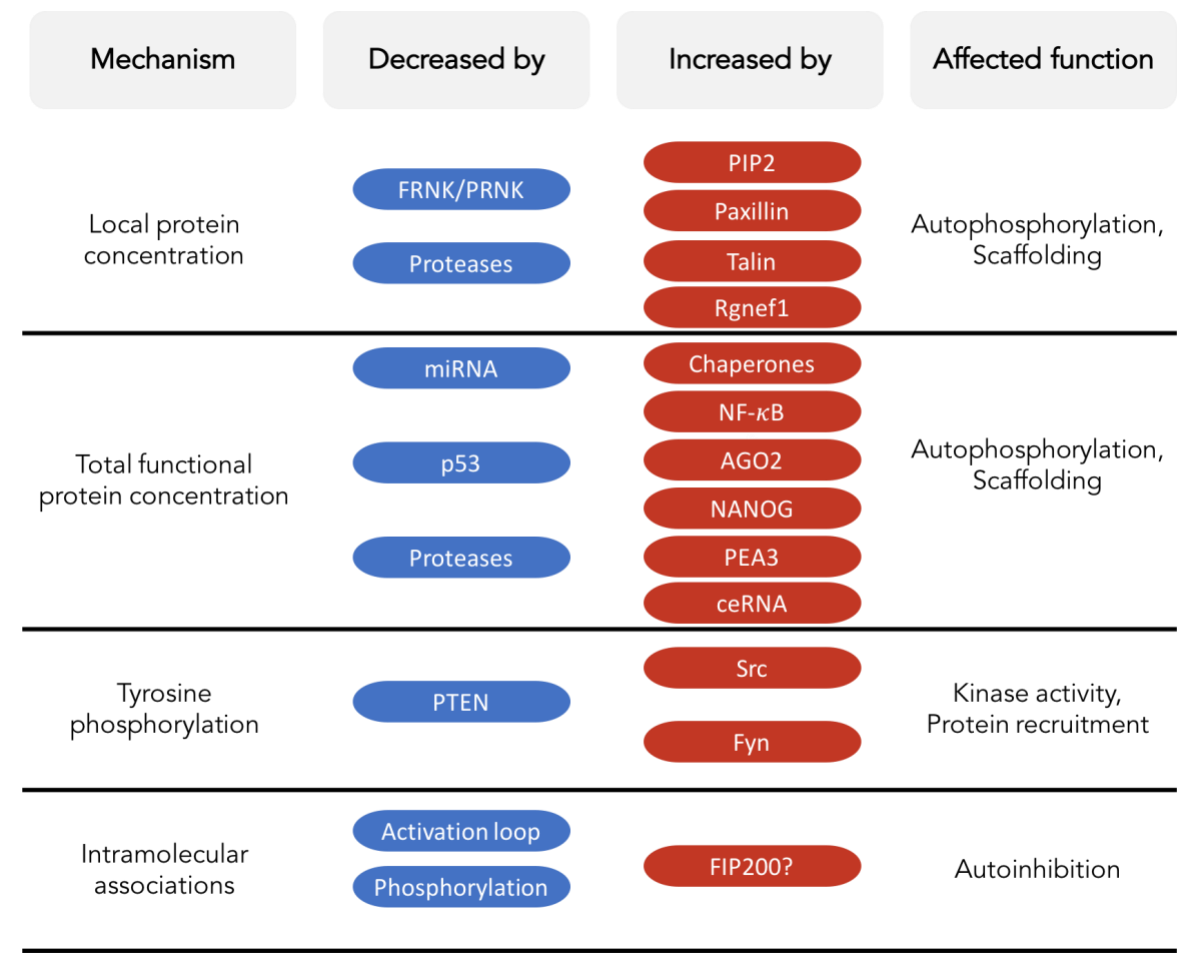

Figure 4. Overview of selected endogenous mechanisms that influence functions of FAK or PYK2. The 'Mechanism' column shows examples of features that affect FAK and PYK2 function, i.e., their local protein concentration, the total amount of correctly folded protein, the degree of tyrosine phosphorylation, and the existence and stability of intramolecular associations, in particular the FERM:kinase autoinhibitory interaction. Selected examples of factors that decrease or increase these mechanisms are shown. For FIP200, the question mark indicates that its influence on intramolecular associations is highly speculative. 
Inhibitors specifically targeting the p53 or Mdm2 binding site on the FERM domain of nuclear FAK are also promising in treating cancers without deleterious mutations of p53 as indicated by an inhibitor of the putative p53 binding site on FAK FERM exhibiting tumor-suppressive effects by dampening FAK-induced p53 degradation [218]. However, the structural basis for these interactions needs to be clarified before they can be used as templates for the rational design of inhibitory small-molecule mimics.

An alternative strategy is to target the self-association mechanisms of FAK and PYK2 needed for their trans-autophosphorylation. Such allosteric protein-protein interaction inhibitors could directly manipulate the molecular control mechanisms of FAK or PYK2 without the risk of severe off-target side effects commonly associated with inhibitors of kinase domains. For FAK, such protein-protein interaction inhibitors could target the FERM or FAT domains, which are required for trans-autophosphorylation, or they could stabilize the inhibitory FERM:kinase association [31,40,46]. Indeed, compounds have been developed that target these mechanisms, including molecules that block access to Y397 or inhibit interactions of the FAT or FERM domains [10,218-222]. Although these compounds were found to lack efficacy and to require micromolar concentrations, they display tumor-suppressive activity in xenograft mouse models and enhance the effect of conventional chemotherapy. However, their specificity and mode of action remain poorly understood [10].

Another promising approach to utilizing endogenous mechanisms for controlling the spread and metastasis of cancer cells may be based on ncRNAs. Their mode of action through direct binding to mRNA is simple and sufficiently well understood, and detailed descriptions of their tumor-suppressive effects are rapidly accumulating. Therapeutic miRNAs or siRNAs are currently emerging as next-generation biopharmaceuticals that can rapidly move from the bench to the clinic, with about 20 molecules currently in clinical trials. Although none of these 20 ncRNAs are targeting FAK or PYK2, most are used to treat cancers, and two are specifically silencing kinases (SYK and PKN3) [223,224]. These proofs of concept of ncRNA-based therapeutics combined with the accruing evidence for the tumor-suppressive effects of miRNA-mediated inhibition of FAK and/or PYK2 suggest that the development of FAK- and/or PYK2-specific anti-cancer mi/siRNA therapies would be worthwhile. Moreover, the biological capacities of the almost 20,000 potentially functional human lncRNAs are only beginning to emerge [225]. In particular, their capacity to act as ceRNA or to directly bind to proteins (see, for example, [226]) might lead to interesting regulatory effects with therapeutic potential. Although to date no lncRNA has been discovered that directly binds to FAK or PYK2, RNA aptamers can potently and selectively inhibit kinases through positioning of an adenine nucleotide into the ATP-binding pocket [227], and more than 40 kinases have been identified as non-classical RNA binding proteins in a screen of the Arabidopsis thaliana proteome [228]. Methods for efficient and specific in vivo delivery of ncRNAs must overcome many challenges, including poor tissue penetration, rapid degradation, immunotoxicity, reliance on cellular factors required for miRNA function and possible off-target effects [229]. Nonetheless, advances in tissue delivery methods and in ncRNA bioengineering and recombinant production methods (e.g., [230]) suggest that ncRNAs are promising nature-inspired agents that can enrich our toolkit of selective therapeutic inhibitors of FAK and PYK2.

\section{Conclusions}

Despite decades of investigations, FAK and PYK2 are still revealing novel or nuanced biological functions. This versatility appears to result, at least in part, from the capacity of FAK and/or PYK2 to associate with a wide range of proteins or other molecules. These interacting molecules can activate the kinase activity, and/or utilize the scaffolding function of FAK and PYK2 in different tissues, cellular conditions or subcellular localizations, resulting in a rich arsenal of functions for both proteins. Accordingly, cells need to evoke an equally rich set of mechanisms to control the activities of FAK and PYK2. Currently these endogenous inhibitory mechanisms appear less understood than activating mechanisms. In combination with chemo-, radio- or immunotherapy FAK inhibitors are now emerging as valuable anti-tumor agents by blocking FAK and/or PYK2 from providing survival mechanisms 
under stress conditions, such as DNA damage or immunological stress. An increase in our molecular and mechanistic understanding of both, activating and inactivating cellular mechanisms would certainly help efforts for rationally improving the current inhibitors of FAK and/or PYK2. A thorough understanding of how these inhibitors affect FAK or PYK2 function may also allow testing their efficacy in other pathologies implicating FAK or PYK2, such as neurodegenerative diseases [231-233].

Author Contributions: R.N., A.A., E.D.-G. and S.T.A. conceived, wrote and illustrated this review.

Funding: This publication was supported by King Abdullah University of Science and Technology (KAUST) through baseline funds and Award No. URF/1/2602-01-01 from the Office of Sponsored Research (OSR).

Acknowledgments: We thank Virginia Unkefer for editorial assistance and Jean-Antoine Girault, Seungbeom Hong, Bilal M. Qureshi and Afaque-Ahmad Momin for suggestions and discussions. We apologize to all colleagues whose research could not be discussed because of space constraints.

Conflicts of Interest: The authors declare no conflict of interest.

\section{References}

1. Alam, T.; Alazmi, M.; Naser, R.; Huser, F.; Momin, A.A.; Walkiewicz, K.W.; Canlas, C.G.; Huser, R.G.; Ali, A.; Merzaban, J.; et al. Proteome-level assessment of origin, prevalence and function of Leucine-Aspartic Acid (LD) motifs. bioRxiv 2018, 278903. [CrossRef]

2. Sebé-Pedrós, A.; Roger, A.J.; Lang, F.B.; King, N.; Ruiz-Trillo, I. Ancient origin of the integrin-mediated adhesion and signaling machinery. Proc. Natl. Acad. Sci. USA 2010, 107, 10142-10147. [CrossRef] [PubMed]

3. Kleinschmidt, E.G.; Schlaepfer, D.D. Focal adhesion kinase signaling in unexpected places. Curr. Opin. Cell Biol. 2017, 45, 24-30. [CrossRef] [PubMed]

4. Arold, S.T. How focal adhesion kinase achieves regulation by linking ligand binding, localization and action. Curr. Opin. Struct. Biol. 2011, 21, 808-813. [CrossRef] [PubMed]

5. Xiong, W.; Parsons, J.T. Induction of Apoptosis after Expression of PYK2, a Tyrosine Kinase Structurally Related to Focal Adhesion Kinase. J. Cell Biol. 1997, 139, 529-539. [CrossRef] [PubMed]

6. Lee, B.Y.; Timpson, P.; Horvath, L.G.; Daly, R.J. FAK signaling in human cancer as a target for therapeutics. Pharmacol. Ther. 2015, 146, 132-149. [CrossRef] [PubMed]

7. Yoon, H.; Dehart, J.P.; Murphy, J.M.; Lim, S.-T.S. Understanding the roles of FAK in cancer: Inhibitors, genetic models, and new insights. J. Histochem. Cytochem. 2015, 63, 114-128. [CrossRef] [PubMed]

8. Tai, Y.-L.; Chen, L.-C.; Shen, T.-L. Emerging roles of focal adhesion kinase in cancer. BioMed Res. Int. 2015, 2015, 690690. [CrossRef] [PubMed]

9. Golubovskaya, V.M.; Palma, N.L.; Zheng, M.; Ho, B.; Magis, A.; Ostrov, D.; Cance, W.G. A small-molecule inhibitor, $5^{\prime}$-O-tritylthymidine, targets FAK and Mdm-2 interaction, and blocks breast and colon tumorigenesis in vivo. Anticancer Agents Med. Chem. 2013, 13, 532-545. [CrossRef] [PubMed]

10. Sulzmaier, F.J.; Jean, C.; Schlaepfer, D.D. FAK in cancer: Mechanistic findings and clinical applications. Nat. Rev. Cancer 2014, 14, 598-610. [CrossRef] [PubMed]

11. Golubovskaya, V.M. Targeting FAK in human cancer: From finding to first clinical trials. Front. Biosci. Landmark Ed. 2014, 19, 687-706. [CrossRef] [PubMed]

12. Tavora, B.; Reynolds, L.E.; Batista, S.; Demircioglu, F.; Fernandez, I.; Lechertier, T.; Lees, D.M.; Wong, P.-P.; Alexopoulou, A.; Elia, G.; et al. Endothelial-cell FAK targeting sensitizes tumours to DNA-damaging therapy. Nature 2014, 514, 112-116. [CrossRef] [PubMed]

13. Serrels, A.; Lund, T.; Serrels, B.; Byron, A.; McPherson, R.C.; von Kriegsheim, A.; Gómez-Cuadrado, L.; Canel, M.; Muir, M.; Ring, J.E.; et al. Nuclear FAK controls chemokine transcription, Tregs, and evasion of anti-tumor immunity. Cell 2015, 163, 160-173. [CrossRef] [PubMed]

14. Jiang, H.; Hegde, S.; Knolhoff, B.L.; Zhu, Y.; Herndon, J.M.; Meyer, M.A.; Nywening, T.M.; Hawkins, W.G.; Shapiro, I.M.; Weaver, D.T.; et al. Targeting focal adhesion kinase renders pancreatic cancers responsive to checkpoint immunotherapy. Nat. Med. 2016, 22, 851-860. [CrossRef] [PubMed]

15. Corsi, J.-M.; Rouer, E.; Girault, J.-A.; Enslen, H. Organization and post-transcriptional processing of focal adhesion kinase gene. BMC Genom. 2006, 7, 198. [CrossRef] [PubMed] 
16. Sieg, D.J.; Ilić, D.; Jones, K.C.; Damsky, C.H.; Hunter, T.; Schlaepfer, D.D. Pyk2 and Src-family protein-tyrosine kinases compensate for the loss of FAK in fibronectin-stimulated signaling events but Pyk2 does not fully function to enhance FAK- cell migration. EMBO J. 1998, 17, 5933-5947. [CrossRef] [PubMed]

17. Weis, S.M.; Lim, S.-T.; Lutu-Fuga, K.M.; Barnes, L.A.; Chen, X.L.; Göthert, J.R.; Shen, T.-L.; Guan, J.-L.; Schlaepfer, D.D.; Cheresh, D.A. Compensatory role for Pyk2 during angiogenesis in adult mice lacking endothelial cell FAK. J. Cell Biol. 2008, 181, 43-50. [CrossRef] [PubMed]

18. Beinke, S.; Phee, H.; Clingan, J.M.; Schlessinger, J.; Matloubian, M.; Weiss, A. Proline-rich tyrosine kinase-2 is critical for CD8 T-cell short-lived effector fate. Proc. Natl. Acad. Sci. USA 2010, 107, 16234-16239. [CrossRef] [PubMed]

19. Chauhan, D.; Hideshima, T.; Pandey, P.; Treon, S.; Teoh, G.; Raje, N.; Rosen, S.; Krett, N.; Husson, H.; Avraham, S.; et al. RAFTK/PYK2-dependent and -independent apoptosis in multiple myeloma cells. Oncogene 1999, 18, 6733-6740. [CrossRef] [PubMed]

20. Zhao, J.; Zheng, C.; Guan, J. Pyk2 and FAK differentially regulate progression of the cell cycle. J. Cell Sci. 2000, 113, 3063-3072. [PubMed]

21. Zhao, J.; Pestell, R.; Guan, J.-L.; Solomon, M.J. Transcriptional Activation of Cyclin D1 Promoter by FAK Contributes to Cell Cycle Progression. Mol. Biol. Cell 2001, 12, 4066-4077. [CrossRef] [PubMed]

22. Zhao, J.; Bian, Z.C.; Yee, K.; Chen, B.P.C.; Chien, S.; Guan, J.-L. Identification of transcription factor KLF8 as a downstream target of focal adhesion kinase in its regulation of cyclin D1 and cell cycle progression. Mol. Cell 2003, 11, 1503-1515. [CrossRef]

23. Kuwabara, K.; Nakaoka, T.; Sato, K.; Nishishita, T.; Sasaki, T.; Yamashita, N. Differential regulation of cell migration and proliferation through proline-rich tyrosine kinase 2 in ENDOTHELIAL CELLS. Endocrinology 2004, 145, 3324-3330. [CrossRef] [PubMed]

24. Ding, Q.; Grammer, J.R.; Nelson, M.A.; Guan, J.-L.; Stewart, J.E.; Gladson, C.L. p27Kip1 and Cyclin D1 are necessary for focal adhesion kinase regulation of cell cycle progression in glioblastoma cells Propagated in vitro and in vivo in the scid Mouse Brain. J. Biol. Chem. 2005, 280, 6802-6815. [CrossRef] [PubMed]

25. Schaller, M.D. Cellular functions of FAK kinases: Insight into molecular mechanisms and novel functions. J. Cell Sci. 2010, 123, 1007-1013. [CrossRef] [PubMed]

26. Walkiewicz, K.W.; Girault, J.-A.; Arold, S.T. How to awaken your nanomachines: Site-specific activation of focal adhesion kinases through ligand interactions. Prog. Biophys. Mol. Biol. 2015, 119, 60-71. [CrossRef] [PubMed]

27. Hall, J.E.; Fu, W.; Schaller, M.D. Focal adhesion kinase: Exploring FAK structure to gain insight into function. Int. Rev. Cell Mol. Biol. 2011, 288, 185-225. [CrossRef] [PubMed]

28. Hall, J.E.; Fu, W.; Schaller, M.D. Chapter Five-Focal Adhesion Kinase: Exploring FAK Structure to Gain Insight into Function. In International Review of Cell and Molecular Biology; Jeon, K.W., Ed.; Academic Press: Cambridge, MA, USA, 2011; Volume 288, pp. 185-225.

29. Lev, S.; Moreno, H.; Martinez, R.; Canoll, P.; Peles, E.; Musacchio, J.M.; Plowman, G.D.; Rudy, B.; Schlessinger, J. Protein tyrosine kinase PYK2 involved in $\mathrm{Ca}^{2+}$-induced regulation of ion channel and MAP kinase functions. Nature 1995, 376, 737-745. [CrossRef] [PubMed]

30. Carvalho, K.; Khalifat, N.; Maniti, O.; Nicolas, C.; Arold, S.; Picart, C.; Ramos, L. Phosphatidylinositol 4,5Bisphosphate-Induced Conformational Change of Ezrin and Formation of Ezrin Oligomers. Biochemistry (Mosc.) 2010, 49, 9318-9327. [CrossRef] [PubMed]

31. Lietha, D.; Cai, X.; Ceccarelli, D.F.J.; Li, Y.; Schaller, M.D.; Eck, M.J. Structural basis for the autoinhibition of Focal Adhesion Kinase. Cell 2007, 129, 1177-1187. [CrossRef] [PubMed]

32. Arold, S.T.; Hoellerer, M.K.; Noble, M.E.M. The Structural Basis of Localization and Signaling by the Focal Adhesion Targeting Domain. Structure 2002, 10, 319-327. [CrossRef]

33. Ossovskaya, V.; Lim, S.-T.; Ota, N.; Schlaepfer, D.; Ilic, D. FAK nuclear export signal sequences. FEBS Lett. 2008, 582, 2402-2406. [CrossRef] [PubMed]

34. Faure, C.; Ramos, M.; Girault, J.-A. Pyk2 cytonuclear localization: Mechanisms and regulation by serine dephosphorylation. Cell. Mol. Life Sci. 2013, 70, 137-152. [CrossRef] [PubMed]

35. Lim, S.-T.; Chen, X.L.; Lim, Y.; Hanson, D.A.; Vo, T.-T.; Howerton, K.; Larocque, N.; Fisher, S.J.; Schlaepfer, D.D.; Ilic, D. Nuclear FAK promotes cell proliferation and survival through FERM-enhanced p53 degradation. Mol. Cell 2008, 29, 9-22. [CrossRef] [PubMed] 
36. Luo, S.-W.; Zhang, C.; Zhang, B.; Kim, C.-H.; Qiu, Y.-Z.; Du, Q.-S.; Mei, L.; Xiong, W.-C. Regulation of heterochromatin remodelling and myogenin expression during muscle differentiation by FAK interaction with MBD2. EMBO J. 2009, 28, 2568-2582. [CrossRef] [PubMed]

37. Dunty, J.M.; Gabarra-Niecko, V.; King, M.L.; Ceccarelli, D.F.J.; Eck, M.J.; Schaller, M.D. FERM Domain Interaction Promotes FAK Signaling. Mol. Cell. Biol. 2004, 24, 5353-5368. [CrossRef] [PubMed]

38. Lipinski, C.A.; Tran, N.L.; Dooley, A.; Pang, Y.-P.; Rohl, C.; Kloss, J.; Yang, Z.; McDonough, W.; Craig, D.; Berens, M.E.; et al. Critical role of the FERM domain in Pyk2 stimulated glioma cell migration. Biochem. Biophys. Res. Commun. 2006, 349, 939-947. [CrossRef] [PubMed]

39. Riggs, D.; Yang, Z.; Kloss, J.; Loftus, J.C. The Pyk2 FERM regulates Pyk2 complex formation and phosphorylation. Cell. Signal. 2011, 23, 288-296. [CrossRef] [PubMed]

40. Brami-Cherrier, K.; Gervasi, N.; Arsenieva, D.; Walkiewicz, K.; Boutterin, M.-C.; Ortega, A.; Leonard, P.G.; Seantier, B.; Gasmi, L.; Bouceba, T.; et al. FAK dimerization controls its kinase-dependent functions at focal adhesions. EMBO J. 2014, 33, 356-370. [CrossRef] [PubMed]

41. Eide, B.L.; Turck, C.W.; Escobedo, J.A. Identification of Tyr-397 as the primary site of tyrosine phosphorylation and pp60src association in the focal adhesion kinase, pp125FAK. Mol. Cell. Biol. 1995, 15, 2819-2827. [CrossRef] [PubMed]

42. Katz, B.-Z.; Miyamoto, S.; Teramoto, H.; Zohar, M.; Krylov, D.; Vinson, C.; Gutkind, J.S.; Yamada, K.M. Direct transmembrane clustering and cytoplasmic dimerization of focal adhesion kinase initiates its tyrosine phosphorylation. Biochim. Biophys. Acta 2002, 1592, 141-152. [CrossRef]

43. Toutant, M.; Costa, A.; Studler, J.-M.; Kadare, G.; Carnaud, M.; Girault, J.-A. Alternative Splicing Controls the Mechanisms of FAK Autophosphorylation. Mol. Cell. Biol. 2002, 22, 7731-7743. [CrossRef] [PubMed]

44. Park, S.-Y.; Avraham, H.K.; Avraham, S. RAFTK/Pyk2 activation is mediated by trans-acting autophosphorylation in a Src-independent manner. J. Biol. Chem. 2004, 279, 33315-33322. [CrossRef] [PubMed]

45. Kohno, T.; Matsuda, E.; Sasaki, H.; Sasaki, T. Protein-tyrosine kinase CAK $\beta / P Y K 2$ is activated by binding $\mathrm{Ca}^{2+} /$ calmodulin to FERM F2 $\alpha 2$ helix and thus forming its dimer. Biochem. J. 2008, 410, 513-523. [CrossRef] [PubMed]

46. Goñi, G.M.; Epifano, C.; Boskovic, J.; Camacho-Artacho, M.; Zhou, J.; Bronowska, A.; Martín, M.T.; Eck, M.J.; Kremer, L.; Gräter, F.; et al. Phosphatidylinositol 4,5-bisphosphate triggers activation of focal adhesion kinase by inducing clustering and conformational changes. Proc. Natl. Acad. Sci. USA 2014, 111, E3177-E3186. [CrossRef] [PubMed]

47. Lulo, J.; Yuzawa, S.; Schlessinger, J. Crystal structures of free and ligand-bound focal adhesion targeting domain of Pyk2. Biochem. Biophys. Res. Commun. 2009, 383, 347-352. [CrossRef] [PubMed]

48. Garron, M.-L.; Arthos, J.; Guichou, J.-F.; McNally, J.; Cicala, C.; Arold, S.T. Structural Basis for the Interaction between Focal Adhesion Kinase and CD4. J. Mol. Biol. 2008, 375, 1320-1328. [CrossRef] [PubMed]

49. Chapman, N.M.; Houtman, J.C.D. Functions of the FAK family kinases in T cells: Beyond actin cytoskeletal rearrangement. Immunol. Res. 2014, 59, 23-34. [CrossRef] [PubMed]

50. Bartos, J.A.; Ulrich, J.D.; Li, H.; Beazely, M.A.; Chen, Y.; MacDonald, J.F.; Hell, J.W. Postsynaptic clustering and activation of Pyk2 by PSD-95. J. Neurosci. 2010, 30, 449-463. [CrossRef] [PubMed]

51. Xie, J.; Allen, K.H.; Marguet, A.; Berghorn, K.A.; Bliss, S.P.; Navratil, A.M.; Guan, J.L.; Roberson, M.S. Analysis of the calcium-dependent regulation of proline-rich tyrosine kinase 2 by gonadotropin-releasing hormone. Mol. Endocrinol. 2008, 22, 2322-2335. [CrossRef] [PubMed]

52. Schaller, M.D. Calcium-dependent Pyk2 activation: A role for calmodulin? Biochem. J. 2008, 410, e3-e4. [CrossRef] [PubMed]

53. Schaller, M.D.; Borgman, C.A.; Parsons, J.T. Autonomous expression of a noncatalytic domain of the focal adhesion-associated protein tyrosine kinase pp125FAK. Mol. Cell. Biol. 1993, 13, 785-791. [CrossRef] [PubMed]

54. Xiong, W.C.; Macklem, M.; Parsons, J.T. Expression and characterization of splice variants of PYK2, a focal adhesion kinase-related protein. J. Cell Sci. 1998, 111, 1981-1991. [PubMed]

55. Nolan, K.; Lacoste, J.; Parsons, J.T. Regulated expression of focal adhesion kinase-related nonkinase, the autonomously expressed C-terminal domain of focal adhesion kinase. Mol. Cell. Biol. 1999, 19, 6120-6129. [CrossRef] [PubMed]

56. Harte, M.T.; Hildebrand, J.D.; Burnham, M.R.; Bouton, A.H.; Parsons, J.T. p130Cas, a Substrate Associated with v-Src and v-Crk, Localizes to Focal Adhesions and Binds to Focal Adhesion Kinase. J. Biol. Chem. 1996, 271, 13649-13655. [CrossRef] [PubMed] 
57. Polte, T.R.; Hanks, S.K. Interaction between focal adhesion kinase and Crk-associated tyrosine kinase substrate p130Cas. Proc. Natl. Acad. Sci. USA 1995, 92, 10678-10682. [CrossRef] [PubMed]

58. Dikic, I.; Tokiwa, G.; Lev, S.; Courtneidge, S.A.; Schlessinger, J. A role for Pyk2 and Src in linking G-protein-coupled receptors with MAP kinase activation. Nature 1996, 383, 547-550. [CrossRef] [PubMed]

59. Avraham, S.; London, R.; Fu, Y.; Ota, S.; Hiregowdara, D.; Li, J.; Jiang, S.; Pasztor, L.M.; White, R.A.; Groopman, J.E.; Avraham, H. Identification and Characterization of a Novel Related Adhesion Focal Tyrosine Kinase (RAFTK) from Megakaryocytes and Brain. J. Biol. Chem. 1995, 270, 27742-27751. [CrossRef] [PubMed]

60. Sasaki, H.; Nagura, K.; Ishino, M.; Tobioka, H.; Kotani, K.; Sasaki, T. Cloning and Characterization of Cell Adhesion Kinase $\beta$, a Novel Protein-tyrosine Kinase of the Focal Adhesion Kinase Subfamily. J. Biol. Chem. 1995, 270, 21206-21219. [CrossRef] [PubMed]

61. Bellis, S.L.; Miller, J.T.; Turner, C.E. Characterization of Tyrosine Phosphorylation of Paxillin in Vitro by Focal Adhesion Kinase. J. Biol. Chem. 1995, 270, 17437-17441. [CrossRef] [PubMed]

62. Chen, H.-C.; Appeddu, P.A.; Parsons, J.T.; Hildebrand, J.D.; Schaller, M.D.; Guan, J.-L. Interaction of Focal Adhesion Kinase with Cytoskeletal Protein Talin. J. Biol. Chem. 1995, 270, 16995-16999. [CrossRef] [PubMed]

63. Zhai, J.; Lin, H.; Nie, Z.; Wu, J.; Cañete-Soler, R.; Schlaepfer, W.W.; Schlaepfer, D.D. Direct interaction of focal adhesion kinase with p190RhoGEF. J. Biol. Chem. 2003, 278, 24865-24873. [CrossRef] [PubMed]

64. Alam, T.; Alazmi, M.; Gao, X.; Arold, S.T. How to find a leucine in a haystack? Structure, ligand recognition and regulation of leucine-aspartic acid (LD) motifs. Biochem. J. 2014, 460, 317-329. [CrossRef] [PubMed]

65. Xu, S.; Liu, Y.; Li, X.; Liu, Y.; Meijers, R.; Zhang, Y.; Wang, J. The binding of DCC-P3 motif and FAK-FAT domain mediates the initial step of netrin-1/DCC signaling for axon attraction. Cell Discov. 2018, 4. [CrossRef] [PubMed]

66. Koshman, Y.E.; Kim, T.; Chu, M.; Engman, S.J.; Iyengar, R.; Robia, S.L.; Samarel, A.M. FRNK inhibition of focal adhesion kinase-dependent signaling and migration in vascular smooth muscle cells. Arterioscler. Thromb. Vasc. Biol. 2010, 30, 2226-2233. [CrossRef] [PubMed]

67. Zak, T.J.; Koshman, Y.E.; Samarel, A.M.; Robia, S.L. Regulation of Focal Adhesion Kinase through a Direct Interaction with an Endogenous Inhibitor. Biochemistry (Mosc.) 2017, 56, 4722-4731. [CrossRef] [PubMed]

68. Richardson, A.; Parsons, J.T. A mechanism for regulation of the adhesion-associated protein tyrosine kinase pp125FAK. Nature 1996, 380, 538-540. [CrossRef] [PubMed]

69. Kadaré, G.; Gervasi, N.; Brami-Cherrier, K.; Blockus, H.; Messari, S.E.; Arold, S.T.; Girault, J.-A. Conformational dynamics of the focal adhesion targeting domain control specific functions of focal adhesion kinase in cells. J. Biol. Chem. 2015, 290, 478-491. [CrossRef] [PubMed]

70. Zheng, Y.; Xia, Y.; Hawke, D.; Halle, M.; Tremblay, M.L.; Gao, X.; Zhou, X.Z.; Aldape, K.; Cobb, M.H.; Xie, K.; et al. FAK phosphorylation by ERK primes Ras-induced tyrosine dephosphorylation of FAK mediated by PIN1 and PTP-PEST. Mol. Cell 2009, 35, 11-25. [CrossRef] [PubMed]

71. Oppermann, F.S.; Gnad, F.; Olsen, J.V.; Hornberger, R.; Greff, Z.; Kéri, G.; Mann, M.; Daub, H. Large-scale Proteomics Analysis of the Human Kinome. Mol. Cell. Proteom. 2009, 8, 1751-1764. [CrossRef] [PubMed]

72. Crouch, D.H.; Fincham, V.J.; Frame, M.C. Targeted proteolysis of the focal adhesion kinase pp125 FAK during c-MYC-induced apoptosis is suppressed by integrin signalling. Oncogene 1996, 12, 2689-2696. [PubMed]

73. Nagata, S.; Golstein, P. The Fas death factor. Science 1995, 267, 1449-1456. [CrossRef] [PubMed]

74. Pitti, R.M.; Marsters, S.A.; Ruppert, S.; Donahue, C.J.; Moore, A.; Ashkenazi, A. Induction of Apoptosis by Apo-2 Ligand, a New Member of the Tumor Necrosis Factor Cytokine Family. J. Biol. Chem. 1996, 271, 12687-12690. [CrossRef] [PubMed]

75. Gervais, F.G.; Thornberry, N.A.; Ruffolo, S.C.; Nicholson, D.W.; Roy, S. Caspases Cleave Focal Adhesion Kinase during Apoptosis to Generate a FRNK-like Polypeptide. J. Biol. Chem. 1998, 273, 17102-17108. [CrossRef] [PubMed]

76. Wen, L.-P.; Fahrni, J.A.; Troie, S.; Guan, J.-L.; Orth, K.; Rosen, G.D. Cleavage of Focal Adhesion Kinase by Caspases during Apoptosis. J. Biol. Chem. 1997, 272, 26056-26061. [CrossRef] [PubMed]

77. Marzia, M.; Chiusaroli, R.; Neff, L.; Kim, N.-Y.; Chishti, A.H.; Baron, R.; Horne, W.C. Calpain is required for normal osteoclast function and is down-regulated by calcitonin. J. Biol. Chem. 2006, 281, 9745-9754. [CrossRef] [PubMed] 
78. Carragher, N.O.; Levkau, B.; Ross, R.; Raines, E.W. Degraded collagen fragments promote rapid disassembly of smooth muscle focal adhesions that correlates with cleavage of pp125FAK, Paxillin, and Talin. J. Cell Biol. 1999, 147, 619-630. [CrossRef] [PubMed]

79. Raja, S.; Avraham, S.; Avraham, H. Tyrosine Phosphorylation of the Novel Protein-tyrosine Kinase RAFTK during an Early Phase of Platelet Activation by an Integrin Glycoprotein IIb-IIIa-independent Mechanism. J. Biol. Chem. 1997, 272, 10941-10947. [CrossRef] [PubMed]

80. Kadaré, G.; Toutant, M.; Formstecher, E.; Corvol, J.-C.; Carnaud, M.; Boutterin, M.-C.; Girault, J.-A. PIAS1-mediated Sumoylation of Focal Adhesion Kinase Activates Its Autophosphorylationn. J. Biol. Chem. 2003, 278, 47434-47440. [CrossRef] [PubMed]

81. Fonseca, C.; Voabil, P.; Carvalho, A.S.; Matthiesen, R. Tools for Protein Posttranslational Modifications Analysis: FAK, a Case Study. In Mass Spectrometry Data Analysis in Proteomics. Methods in Molecular Biology; Humana Press: Totowa, NJ, USA, 2013; pp. 335-358, ISBN 978-1-62703-391-6.

82. Tomar, A.; Schlaepfer, D.D. A PAK-activated linker for EGFR and FAK. Dev. Cell 2010, 18, 170-172. [CrossRef] [PubMed]

83. Schlaepfer, D.D.; Hunter, T. Evidence for in vivo phosphorylation of the Grb2 SH2-domain binding site on focal adhesion kinase by Src-family protein-tyrosine kinases. Mol. Cell. Biol. 1996, 16, 5623-5633. [CrossRef] [PubMed]

84. Schlaepfer, D.D.; Jones, K.C.; Hunter, T. Multiple Grb2-mediated integrin-stimulated signaling pathways to ERK2/mitogen-activated protein kinase: Summation of both c-Src- and focal adhesion kinase-initiated tyrosine phosphorylation events. Mol. Cell. Biol. 1998, 18, 2571-2585. [CrossRef] [PubMed]

85. Shen, X.; Xi, G.; Radhakrishnan, Y.; Clemmons, D.R. Recruitment of Pyk2 to SHPS-1 signaling complex is required for IGF-I-dependent mitogenic signaling in vascular smooth muscle cells. Cell. Mol. Life Sci. 2010, 67, 3893-3903. [CrossRef] [PubMed]

86. Blaukat, A.; Ivankovic-Dikic, I.; Grönroos, E.; Dolfi, F.; Tokiwa, G.; Vuori, K.; Dikic, I. Adaptor proteins Grb2 and Crk couple Pyk2 with activation of specific mitogen-activated protein kinase cascades. J. Biol. Chem. 1999, 274, 14893-14901. [CrossRef] [PubMed]

87. Zheng, Y.; Yang, W.; Xia, Y.; Hawke, D.; Liu, D.X.; Lu, Z. Ras-Induced and extracellular signal-regulated kinase 1 and 2 phosphorylation-dependent isomerization of protein tyrosine phosphatase (PTP)-PEST by PIN1 Promotes FAK Dephosphorylation by PTP-PEST. Mol. Cell. Biol. 2011, 31, 4258-4269. [CrossRef] [PubMed]

88. Yi, X.P.; Zhou, J.; Huber, L.; Qu, J.; Wang, X.; Gerdes, A.M.; Li, F. Nuclear compartmentalization of FAK and FRNK in cardiac myocytes. Am. J. Physiol. 2006, 290, H2509-H2515. [CrossRef] [PubMed]

89. Schaller, M.D.; Hildebrand, J.D.; Shannon, J.D.; Fox, J.W.; Vines, R.R.; Parsons, J.T. Autophosphorylation of the focal adhesion kinase, pp125FAK, directs SH2-dependent binding of pp60src. Mol. Cell. Biol. 1994, 14, 1680-1688. [CrossRef] [PubMed]

90. Arold, S.T.; Ulmer, T.S.; Mulhern, T.D.; Werner, J.M.; Ladbury, J.E.; Campbell, I.D.; Noble, M.E.M. The Role of the Src Homology 3-Src Homology 2 Interface in the Regulation of Src Kinases. J. Biol. Chem. 2001, 276, 17199-17205. [CrossRef] [PubMed]

91. Mitra, S.K.; Schlaepfer, D.D. Integrin-regulated FAK-Src signaling in normal and cancer cells. Curr. Opin. Cell Biol. 2006, 18, 516-523. [CrossRef] [PubMed]

92. Wilkinson, S.; Hou, Y.; Zoine, J.T.; Saltz, J.; Zhang, C.; Chen, Z.; Cooper, L.A.D.; Marcus, A.I. Coordinated cell motility is regulated by a combination of LKB1 farnesylation and kinase activity. Sci. Rep. 2017, 7, 40929. [CrossRef] [PubMed]

93. Kline, E.R.; Shupe, J.; Gilbert-Ross, M.; Zhou, W.; Marcus, A.I. LKB1 Represses Focal Adhesion Kinase (FAK) Signaling via a FAK-LKB1 Complex to Regulate FAK Site Maturation and Directional Persistence. J. Biol. Chem. 2013, 288, 17663-17674. [CrossRef] [PubMed]

94. Konen, J.; Wilkinson, S.; Lee, B.; Fu, H.; Zhou, W.; Jiang, Y.; Marcus, A.I. LKB1 kinase-dependent and -independent defects disrupt polarity and adhesion signaling to drive collagen remodeling during invasion. Mol. Biol. Cell 2016, 27, 1069-1084. [CrossRef] [PubMed]

95. Ding, L.; Getz, G.; Wheeler, D.A.; Mardis, E.R.; McLellan, M.D.; Cibulskis, K.; Sougnez, C.; Greulich, H.; Muzny, D.M.; Morgan, M.B.; et al. Somatic mutations affect key pathways in lung adenocarcinoma. Nature 2008, 455, 1069-1075. [CrossRef] [PubMed] 
96. Carretero, J.; Medina, P.P.; Pio, R.; Montuenga, L.M.; Sanchez-Cespedes, M. Novel and natural knockout lung cancer cell lines for the LKB1/STK11 tumor suppressor gene. Oncogene 2004, 23, 4037-4040. [CrossRef] [PubMed]

97. Sanchez-Cespedes, M.; Parrella, P.; Esteller, M.; Nomoto, S.; Trink, B.; Engles, J.M.; Westra, W.H.; Herman, J.G.; Sidransky, D. Inactivation of LKB1/STK11 is a common event in adenocarcinomas of the lung. Cancer Res. 2002, 62, 3659-3662. [PubMed]

98. Zeqiraj, E.; Filippi, B.M.; Deak, M.; Alessi, D.R.; van Aalten, D.M.F. Structure of the LKB1-STRAD-MO25 complex reveals an allosteric mechanism of kinase activation. Science 2009, 326, 1707-1711. [CrossRef] [PubMed]

99. Ritho, J.; Arold, S.T.; Yeh, E.T.H. A Critical SUMO1 Modification of LKB1 Regulates AMPK Activity during Energy Stress. Cell Rep. 2015, 12, 734-742. [CrossRef] [PubMed]

100. Carretero, J.; Shimamura, T.; Rikova, K.; Jackson, A.L.; Wilkerson, M.D.; Borgman, C.L.; Buttarazzi, M.S.; Sanofsky, B.A.; McNamara, K.L.; Brandstetter, K.A.; et al. Integrative genomic and proteomic analyses identify targets for Lkb1 deficient metastatic lung tumors. Cancer Cell 2010, 17, 547-559. [CrossRef] [PubMed]

101. Goodwin, J.M.; Svensson, R.U.; Lou, H.J.; Winslow, M.M.; Turk, B.E.; Shaw, R.J. An AMPK-independent signaling pathway downstream of the LKB1 tumor suppressor controls Snail1 and metastatic potential. Mol. Cell 2014, 55, 436-450. [CrossRef] [PubMed]

102. Chan, K.-C.; Lin, M.-C.; Huang, C.-N.; Chang, W.-C.; Wang, C.-J. Mulberry 1-Deoxynojirimycin Pleiotropically Inhibits Glucose-Stimulated Vascular Smooth Muscle Cell Migration by Activation of AMPK/RhoB and Down-regulation of FAK. J. Agric. Food Chem. 2013, 61, 9867-9875. [CrossRef] [PubMed]

103. Suzuki, A.; Kusakai, G.; Kishimoto, A.; Minegichi, Y.; Ogura, T.; Esumi, H. Induction of cell-cell detachment during glucose starvation through F-actin conversion by SNARK, the fourth member of the AMP-activated protein kinase catalytic subunit family. Biochem. Biophys. Res. Commun. 2003, 311, 156-161. [CrossRef] [PubMed]

104. Lassiter, D.G.; Nylén, C.; Sjögren, R.J.O.; Chibalin, A.V.; Wallberg-Henriksson, H.; Näslund, E.; Krook, A.; Zierath, J.R. FAK tyrosine phosphorylation is regulated by AMPK and controls metabolism in human skeletal muscle. Diabetologia 2018, 61, 424-432. [CrossRef] [PubMed]

105. Chen, H.C.; Bandyopadhyay, G.; Sajan, M.P.; Kanoh, Y.; Standaert, M.; Farese, R.V.; Farese, R.V. Activation of the ERK pathway and atypical protein kinase $C$ isoforms in exercise- and aminoimidazole-4-carboxamide-1beta-D-riboside (AICAR)-stimulated glucose transport. J. Biol. Chem. 2002, 277, 23554-23562. [CrossRef] [PubMed]

106. Kim, E.-K.; Park, J.-M.; Lim, S.; Choi, J.W.; Kim, H.S.; Seok, H.; Seo, J.K.; Oh, K.; Lee, D.-S.; Kim, K.T.; et al. Activation of AMP-activated protein kinase is essential for lysophosphatidic acid-induced cell migration in ovarian cancer cells. J. Biol. Chem. 2011, 286, 24036-24045. [CrossRef] [PubMed]

107. Zhang, X.C.; Piccini, A.; Myers, M.P.; Van Aelst, L.; Tonks, N.K. Functional analysis of the protein phosphatase activity of PTEN. Biochem. J. 2012, 444, 457-464. [CrossRef] [PubMed]

108. Worby, C.A.; Dixon, J.E. PTEN. Annu. Rev. Biochem. 2014, 83, 641-669. [CrossRef] [PubMed]

109. Zhang, J.; Gao, X.; Schmit, F.; Adelmant, G.; Eck, M.J.; Marto, J.A.; Zhao, J.J.; Roberts, T.M. CRKL Mediates p110ß-Dependent PI3K Signaling in PTEN-Deficient Cancer Cells. Cell Rep. 2017, 20, 549-557. [CrossRef] [PubMed]

110. Lu, Q.; Rounds, S. Focal Adhesion Kinase and Endothelial Cell Apoptosis. Microvasc. Res. 2012, 83, 56-63. [CrossRef] [PubMed]

111. Haddadi, N.; Lin, Y.; Travis, G.; Simpson, A.M.; McGowan, E.M.; Nassif, N.T. PTEN/PTENP1: 'Regulating the regulator of RTK-dependent PI3K/Akt signalling', new targets for cancer therapy. Mol. Cancer 2018, 17. [CrossRef] [PubMed]

112. Zhang, L.-L.; Liu, J.; Lei, S.; Zhang, J.; Zhou, W.; Yu, H.-G. PTEN inhibits the invasion and metastasis of gastric cancer via downregulation of FAK expression. Cell. Signal. 2014, 26, 1011-1020. [CrossRef] [PubMed]

113. Wang, S.-Y.; Hao, H.-L.; Deng, K.; Li, Y.; Cheng, Z.-Y.; Lv, C.; Liu, Z.-M.; Yang, J.; Pan, L. Expression levels of phosphatase and tensin homolog deleted on chromosome 10 (PTEN) and focal adhesion kinase in patients with multiple myeloma and their relationship to clinical stage and extramedullary infiltration. Leuk. Lymphoma 2012, 53, 1162-1168. [CrossRef] [PubMed]

114. Tamura, M.; Gu, J.; Danen, E.H.; Takino, T.; Miyamoto, S.; Yamada, K.M. PTEN interactions with focal adhesion kinase and suppression of the extracellular matrix-dependent phosphatidylinositol 3-kinase/Akt cell survival pathway. J. Biol. Chem. 1999, 274, 20693-20703. [CrossRef] [PubMed] 
115. Haier, J.; Nicolson, G.L. PTEN regulates tumor cell adhesion of colon carcinoma cells under dynamic conditions of fluid flow. Oncogene 2002, 21, 1450-1460. [CrossRef] [PubMed]

116. Chen, H.C.; Guan, J.L. Association of focal adhesion kinase with its potential substrate phosphatidylinositol 3-kinase. Proc. Natl. Acad. Sci. USA 1994, 91, 10148-10152. [CrossRef] [PubMed]

117. Lim, S.-T.; Mikolon, D.; Stupack, D.G.; Schlaepfer, D.D. FERM control of FAK function: Implications for cancer therapy. Cell Cycle Georget. Tex 2008, 7, 2306-2314. [CrossRef] [PubMed]

118. Ross, A.H.; Gericke, A. Phosphorylation keeps PTEN phosphatase closed for business. Proc. Natl. Acad. Sci. USA 2009, 106, 1297-1298. [CrossRef] [PubMed]

119. Tzenaki, N.; Aivaliotis, M.; Papakonstanti, E.A. Focal adhesion kinase phosphorylates the phosphatase and tensin homolog deleted on chromosome 10 under the control of p1108 phosphoinositide-3 kinase. FASEB J. 2015, 29, 4840-4852. [CrossRef] [PubMed]

120. Ueda, H.; Abbi, S.; Zheng, C.; Guan, J.L. Suppression of Pyk2 kinase and cellular activities by FIP200. J. Cell Biol. 2000, 149, 423-430. [CrossRef] [PubMed]

121. Chano, T.; Ikegawa, S.; Saito-Ohara, F.; Inazawa, J.; Mabuchi, A.; Saeki, Y.; Okabe, H. Isolation, characterization and mapping of the mouse and human RB1CC1 genes. Gene 2002, 291, 29-34. [CrossRef]

122. Gan, B.; Guan, J.-L. FIP200, a key signaling node to coordinately regulate various cellular processes. Cell. Signal. 2008, 20, 787-794. [CrossRef] [PubMed]

123. Chano, T.; Ikegawa, S.; Kontani, K.; Okabe, H.; Baldini, N.; Saeki, Y. Identification of RB1CC1, a novel human gene that can induce RB1 in various human cells. Oncogene 2002, 21, 1295-1298. [CrossRef] [PubMed]

124. Chano, T.; Kontani, K.; Teramoto, K.; Okabe, H.; Ikegawa, S. Truncating mutations of RB1CC1 in human breast cancer. Nat. Genet. 2002, 31, 285-288. [CrossRef] [PubMed]

125. Abbi, S.; Ueda, H.; Zheng, C.; Cooper, L.A.; Zhao, J.; Christopher, R.; Guan, J.-L. Regulation of focal adhesion kinase by a novel protein inhibitor FIP200. Mol. Biol. Cell. 2002, 13, 3178-3191. [CrossRef] [PubMed]

126. Wang, D.; Olman, M.A.; Stewart, J.; Tipps, R.; Huang, P.; Sanders, P.W.; Toline, E.; Prayson, R.A.; Lee, J.; Weil, R.J.; et al. Downregulation of FIP200 induces apoptosis of glioblastoma cells and microvascular endothelial cells by enhancing Pyk2 activity. PLoS ONE 2011, 6, e19629. [CrossRef] [PubMed]

127. Calderwood, S.K.; Murshid, A. Molecular Chaperone Accumulation in Cancer and Decrease in Alzheimer's Disease: The Potential Roles of HSF1. Front. Neurosci. 2017, 11, 192. [CrossRef] [PubMed]

128. Taipale, M.; Krykbaeva, I.; Koeva, M.; Kayatekin, C.; Westover, K.D.; Karras, G.I.; Lindquist, S. Quantitative analysis of HSP90-client interactions reveals principles of substrate recognition. Cell 2012, 150, 987-1001. [CrossRef] [PubMed]

129. Taipale, M.; Jarosz, D.F.; Lindquist, S. HSP90 at the hub of protein homeostasis: Emerging mechanistic insights. Nat. Rev. Mol. Cell. Biol. 2010, 11, 515-528. [CrossRef] [PubMed]

130. Dobbelstein, M.; Moll, U. Targeting tumour-supportive cellular machineries in anticancer drug development. Nat. Rev. Drug Discov. 2014, 13, 179-196. [CrossRef] [PubMed]

131. Calderwood, S.K.; Gong, J. Heat Shock Proteins Promote Cancer: It's a Protection Racket. Trends Biochem. Sci. 2016, 41, 311-323. [CrossRef] [PubMed]

132. Xiong, X.; Wang, Y.; Liu, C.; Lu, Q.; Liu, T.; Chen, G.; Rao, H.; Luo, S. Heat shock protein 90beta stabilizes focal adhesion kinase and enhances cell migration and invasion in breast cancer cells. Exp. Cell. Res. 2014, 326, 78-89. [CrossRef] [PubMed]

133. Verba, K.A.; Wang, R.Y.; Arakawa, A.; Liu, Y.; Shirouzu, M.; Yokoyama, S.; Agard, D.A. Atomic structure of Hsp90-Cdc37-Cdk4 reveals that Hsp90 traps and stabilizes an unfolded kinase. Science 2016, 352, 1542-1547. [CrossRef] [PubMed]

134. Caino, M.C.; Chae, Y.C.; Vaira, V.; Ferrero, S.; Nosotti, M.; Martin, N.M.; Weeraratna, A.; O'Connell, M.; Jernigan, D.; Fatatis, A.; et al. Metabolic stress regulates cytoskeletal dynamics and metastasis of cancer cells. J. Clin. Investig. 2013, 123, 2907-2920. [CrossRef] [PubMed]

135. Lin, Y.; Peng, N.; Zhuang, H.; Zhang, D.; Wang, Y.; Hua, Z.C. Heat shock proteins HSP70 and MRJ cooperatively regulate cell adhesion and migration through urokinase receptor. BMC Cancer 2014, 14, 639. [CrossRef] [PubMed] 
136. Huang, J.; Che, M.I.; Lin, N.Y.; Hung, J.S.; Huang, Y.T.; Lin, W.C.; Huang, H.C.; Lee, P.H.; Liang, J.T.; Huang, M.C. The molecular chaperone Cosmc enhances malignant behaviors of colon cancer cells via activation of Akt and ERK. Mol. Carcinog. 2014, 53, E62-E71. [CrossRef] [PubMed]

137. Cheng, N.; Li, Y.; Han, Z.-G. Argonaute2 promotes tumor metastasis by way of up-regulating focal adhesion kinase expression in hepatocellular carcinoma. Hepatol. Baltim. Md 2013, 57, 1906-1918. [CrossRef] [PubMed]

138. Li, S.; Huang, X.; Zhang, D.; Huang, Q.; Pei, G.; Wang, L.; Jiang, W.; Hu, Q.; Tan, R.; Hua, Z.-C. Requirement of PEA3 for Transcriptional Activation of FAK Gene in Tumor Metastasis. PLoS ONE 2013, 8. [CrossRef] [PubMed]

139. Ho, B.; Olson, G.; Figel, S.; Gelman, I.; Cance, W.G.; Golubovskaya, V.M. Nanog increases focal adhesion kinase (FAK) promoter activity and expression and directly binds to FAK protein to be phosphorylated. J. Biol. Chem. 2012, 287, 18656-18673. [CrossRef] [PubMed]

140. Golubovskaya, V.M.; Finch, R.; Kweh, F.; Massoll, N.A.; Campbell-Thompson, M.; Wallace, M.R.; Cance, W.G. p53 regulates FAK expression in human tumor cells. Mol. Carcinog. 2008, 47, 373-382. [CrossRef] [PubMed]

141. Takahashi, A.; Suzuki, H.; Omori, K.; Seki, M.; Hashizume, T.; Shimazu, T.; Ishioka, N.; Ohnishi, T. Expression of p53-regulated proteins in human cultured lymphoblastoid TSCE5 and WTK1 cell lines during spaceflight. J. Radiat. Res. (Tokyo) 2012, 53, 168-175. [CrossRef]

142. Lim, S.-T.; Miller, N.L.G.; Nam, J.-O.; Chen, X.L.; Lim, Y.; Schlaepfer, D.D. Pyk2 inhibition of p53 as an adaptive and intrinsic mechanism facilitating cell proliferation and survival. J. Biol. Chem. 2010, 285, 1743-1753. [CrossRef] [PubMed]

143. Golubovskaya, V.; Kaur, A.; Cance, W. Cloning and characterization of the promoter region of human focal adhesion kinase gene: nuclear factor kappa B and p53 binding sites. Biochim. Biophys. Acta 2004, 1678, 111-125. [CrossRef] [PubMed]

144. Golubovskaya, V.M.; Conway-Dorsey, K.; Edmiston, S.N.; Tse, C.-K.; Lark, A.A.; Livasy, C.A.; Moore, D.; Millikan, R.C.; Cance, W.G. FAK overexpression and p53 mutations are highly correlated in human breast cancer. Int. J. Cancer 2009, 125, 1735-1738. [CrossRef] [PubMed]

145. Tyner, S.D.; Venkatachalam, S.; Choi, J.; Jones, S.; Ghebranious, N.; Igelmann, H.; Lu, X.; Soron, G.; Cooper, B.; Brayton, C.; et al. p53 mutant mice that display early ageing-associated phenotypes. Nature 2002, 415, 45-53. [CrossRef] [PubMed]

146. Ventura, A.; Kirsch, D.G.; McLaughlin, M.E.; Tuveson, D.A.; Grimm, J.; Lintault, L.; Newman, J.; Reczek, E.E.; Weissleder, R.; Jacks, T. Restoration of p53 function leads to tumour regression in vivo. Nature 2007, 445, 661-665. [CrossRef] [PubMed]

147. Mattick, J.S.; Makunin, I.V. Non-coding RNA. Hum. Mol. Genet. 2006, 15, R17-R29. [CrossRef] [PubMed]

148. Morris, K.V. (Ed.) Non-Coding RNAs and Epigenetic Regulation of Gene Expression: Drivers of Natural Selection; Caister Academic Press: Poole, UK, 2014; Volume 89, p. 182. [CrossRef]

149. Bartel, D.P. MicroRNAs: Genomics, biogenesis, mechanism, and function. Cell 2004, 116, 281-297. [CrossRef]

150. Filipowicz, W.; Bhattacharyya, S.N.; Sonenberg, N. Mechanisms of post-transcriptional regulation by microRNAs: Are the answers in sight? Nat. Rev. Genet. 2008, 9, 102-114. [CrossRef] [PubMed]

151. Kasinski, A.L.; Slack, F.J. Epigenetics and genetics. MicroRNAs en route to the clinic: Progress in validating and targeting microRNAs for cancer therapy. Nat. Rev. Cancer 2011, 11, 849-864. [CrossRef] [PubMed]

152. Zhuang, Y.; Peng, H.; Mastej, V.; Chen, W. MicroRNA regulation of endothelial junction proteins and clinical consequence. Mediat. Inflamm. 2016, 2016, 5078627. [CrossRef] [PubMed]

153. Kumar, M.S.; Lu, J.; Mercer, K.L.; Golub, T.R.; Jacks, T. Impaired microRNA processing enhances cellular transformation and tumorigenesis. Nat. Genet. 2007, 39, 673-677. [CrossRef] [PubMed]

154. Zhao, J.; Tao, Y.; Zhou, Y.; Qin, N.; Chen, C.; Tian, D.; Xu, L. MicroRNA-7: A promising new target in cancer therapy. Cancer Cell Int. 2015, 15, 103. [CrossRef] [PubMed]

155. Wu, D.G.; Wang, Y.Y.; Fan, L.G.; Luo, H.; Han, B.; Sun, L.H.; Wang, X.F.; Zhang, J.X.; Cao, L.; Wang, X.R.; et al. MicroRNA-7 regulates glioblastoma cell invasion via targeting focal adhesion kinase expression. Chin. Med. J. (Engl.) 2011, 124, 2616-2621. [PubMed]

156. Zeng, C.Y.; Zhan, Y.S.; Huang, J.; Chen, Y.X. MicroRNA7 suppresses human colon cancer invasion and proliferation by targeting the expression of focal adhesion kinase. Mol. Med. Rep. 2016, 13, 1297-1303. [CrossRef] [PubMed]

157. Kong, X.; Li, G.; Yuan, Y.; He, Y.; Wu, X.; Zhang, W.; Wu, Z.; Chen, T.; Wu, W.; Lobie, P.E.; et al. MicroRNA-7 inhibits epithelial-to-mesenchymal transition and metastasis of breast cancer cells via targeting FAK expression. PLoS ONE 2012, 7, e41523. [CrossRef] [PubMed] 
158. Cao, Q.; Mao, Z.D.; Shi, Y.J.; Chen, Y.; Sun, Y.; Zhang, Q.; Song, L.; Peng, L.P. MicroRNA-7 inhibits cell proliferation, migration and invasion in human non-small cell lung cancer cells by targeting FAK through ERK/MAPK signaling pathway. Oncotarget 2016, 7, 77468-77481. [CrossRef] [PubMed]

159. Lee, K.M.; Choi, E.J.; Kim, I.A. microRNA-7 increases radiosensitivity of human cancer cells with activated EGFR-associated signaling. Radiother. Oncol. 2011, 101, 171-176. [CrossRef] [PubMed]

160. Taylor, K.N.; Schlaepfer, D.D. Adaptive resistance to chemotherapy, a multi-FAK-torial linkage. Mol. Cancer Ther. 2018, 17, 719-723. [CrossRef] [PubMed]

161. Hochwald, S.N.; Nyberg, C.; Zheng, M.; Zheng, D.; Wood, C.; Massoll, N.A.; Magis, A.; Ostrov, D.; Cance, W.G.; Golubovskaya, V.M. A novel small molecule inhibitor of FAK decreases growth of human pancreatic cancer. Cell Cycle Georget. Tex. 2009, 8, 2435-2443. [CrossRef] [PubMed]

162. Kurenova, E.V.; Liao, J.; He, D.; Hunt, D.L.; Chekhau, A.; Hochwald, S.N.; Ostrov, D.A.; Cance, W.G. Effect of a novel FAK inhibitor targeted to the binding site of VEGFR3 on pancreatic cancer proliferation in vitro and in vivo. J. Clin. Oncol. 2011, 29, 214. [CrossRef]

163. Zhou, Y.; Dang, J.; Chang, K.Y.; Yau, E.; Aza-Blanc, P.; Moscat, J.; Rana, T.M. MiR-1298 Inhibits Mutant KRAS-Driven Tumor Growth by Repressing FAK and LAMB3. Cancer Res. 2016, 76, 5777-5787. [CrossRef] [PubMed]

164. Schlaepfer, D.D.; Hanks, S.K.; Hunter, T.; van der Geer, P. Integrin-mediated signal transduction linked to Ras pathway by GRB2 binding to focal adhesion kinase. Nature 1994, 372, 786-791. [CrossRef] [PubMed]

165. Konstantinidou, G.; Ramadori, G.; Torti, F.; Kangasniemi, K.; Ramirez, R.E.; Cai, Y.; Behrens, C.; Dellinger, M.T.; Brekken, R.A.; Wistuba, I.I.; et al. RHOA-FAK is a required signaling axis for the maintenance of KRAS-driven lung adenocarcinomas. Cancer Discov. 2013, 3, 444-457. [CrossRef] [PubMed]

166. Bing, L.; Hong, C.; Li-Xin, S.; Wei, G. MicroRNA-543 suppresses endometrial cancer oncogenicity via targeting FAK and TWIST1 expression. Arch. Gynecol. Obstet. 2014, 290, 533-541. [CrossRef] [PubMed]

167. Chen, J.S.; Li, H.S.; Huang, J.Q.; Dong, S.H.; Huang, Z.J.; Yi, W.; Zhan, G.F.; Feng, J.T.; Sun, J.C.; Huang, X.H. MicroRNA-379-5p inhibits tumor invasion and metastasis by targeting FAK/AKT signaling in hepatocellular carcinoma. Cancer Lett. 2016, 375, 73-83. [CrossRef] [PubMed]

168. Mazzu, Y.Z.; Hu, Y.; Soni, R.K.; Mojica, K.M.; Qin, L.X.; Agius, P.; Waxman, Z.M.; Mihailovic, A.; Socci, N.D.; Hendrickson, R.C.; et al. MiR-193b-regulated signaling networks serve as tumor suppressors in liposarcoma and promote adipogenesis in adipose-derived stem cells. Cancer Res. 2017, 77, 5728-5740. [CrossRef] [PubMed]

169. Majid, S.; Saini, S.; Dar, A.A.; Hirata, H.; Shahryari, V.; Tanaka, Y.; Yamamura, S.; Ueno, K.; Zaman, M.S.; Singh, K.; et al. MicroRNA-205 inhibits Src-mediated oncogenic pathways in renal cancer. Cancer Res. 2011, 71, 2611-2621. [CrossRef] [PubMed]

170. Wang, N.; Li, Q.; Feng, N.H.; Cheng, G.; Guan, Z.L.; Wang, Y.; Qin, C.; Yin, C.J.; Hua, L.X. miR-205 is frequently downregulated in prostate cancer and acts as a tumor suppressor by inhibiting tumor growth. Asian J. Androl. 2013, 15, 735-741. [CrossRef] [PubMed]

171. Li, J.; Bai, H.; Zhu, Y.; Wang, X.Y.; Wang, F.; Zhang, J.W.; Lavker, R.M.; Yu, J. Antagomir dependent microRNA-205 reduction enhances adhesion ability of human corneal epithelial keratinocytes. Chin. Med. Sci. J. 2010, 25, 65-70. [CrossRef]

172. Rashed, M.H.; Kanlikilicer, P.; Rodriguez-Aguayo, C.; Pichler, M.; Bayraktar, R.; Bayraktar, E.; Ivan, C.; Filant, J.; Silva, A.; Aslan, B.; et al. Exosomal miR-940 maintains SRC-mediated oncogenic activity in cancer cells: A possible role for exosomal disposal of tumor suppressor miRNAs. Oncotarget 2017, 8, 20145-20164. [CrossRef] [PubMed]

173. Egawa, H.; Jingushi, K.; Hirono, T.; Ueda, Y.; Kitae, K.; Nakata, W.; Fujita, K.; Uemura, M.; Nonomura, N.; Tsujikawa, K. The miR-130 family promotes cell migration and invasion in bladder cancer through FAK and Akt phosphorylation by regulating PTEN. Sci. Rep. 2016, 6, 20574. [CrossRef] [PubMed]

174. Cui, L.; Li, Y.; Lv, X.; Li, J.; Wang, X.; Lei, Z.; Li, X. Expression of MicroRNA-301a and its Functional Roles in Malignant Melanoma. Cell. Physiol. Biochem. 2016, 40, 230-244. [CrossRef] [PubMed]

175. Tang, H.; Yao, L.; Tao, X.; Yu, Y.; Chen, M.; Zhang, R.; Xu, C. miR-9 functions as a tumor suppressor in ovarian serous carcinoma by targeting TLN1. Int. J. Mol. Med. 2013, 32, 381-388. [CrossRef] [PubMed]

176. Wang, Q.; Li, X.; Zhu, Y.; Yang, P. MicroRNA-16 suppresses epithelial-mesenchymal transitionrelated gene expression in human glioma. Mol. Med. Rep. 2014, 10, 3310-3314. [CrossRef] [PubMed] 
177. Du, W.W.; Li, X.; Li, T.; Li, H.; Khorshidi, A.; Liu, F.; Yang, B.B. The microRNA miR-17-3p inhibits mouse cardiac fibroblast senescence by targeting Par4. J. Cell. Sci. 2015, 128, 293-304. [CrossRef] [PubMed]

178. Ren, Y.; Zhou, X.; Yang, J.J.; Liu, X.; Zhao, X.H.; Wang, Q.X.; Han, L.; Song, X.; Zhu, Z.Y.; Tian, W.P.; et al. AC1MMYR2 impairs high dose paclitaxel-induced tumor metastasis by targeting miR-21/CDK5 axis. Cancer Lett. 2015, 362, 174-182. [CrossRef] [PubMed]

179. De Antonellis, P.; Carotenuto, M.; Vandenbussche, J.; de Vita, G.; Ferrucci, V.; Medaglia, C.; Boffa, I.; Galiero, A.; Di Somma, S.; Magliulo, D.; et al. Early targets of miR-34a in neuroblastoma. Mol. Cell. Proteomics 2014, 13, 2114-2131. [CrossRef] [PubMed]

180. Zhang, D.; Zhou, J.; Dong, M. Dysregulation of microRNA-34a expression in colorectal cancer inhibits the phosphorylation of FAK via VEGF. Dig. Sci. 2014, 59, 958-967. [CrossRef] [PubMed]

181. Ma, G.; Jing, C.; Li, L.; Huang, F.; Ding, F.; Wang, B.; Lin, D.; Luo, A.; Liu, Z. MicroRNA-92b represses invasion-metastasis cascade of esophageal squamous cell carcinoma. Oncotarget 2016, 7, 20209-20222. [CrossRef] [PubMed]

182. Cai, J.J.; Qi, Z.X.; Chen, L.C.; Yao, Y.; Gong, Y.; Mao, Y. miR-124 suppresses the migration and invasion of glioma cells in vitro via Capn4. Oncol. Rep. 2016, 35, 284-290. [CrossRef] [PubMed]

183. Gao, F.; Wang, F.G.; Liu, R.R.; Xue, F.; Zhang, J.; Xu, G.Q.; Bi, J.H.; Meng, Z.; Huo, R. Epigenetic silencing of miR-130a ameliorates hemangioma by targeting tissue factor pathway inhibitor 2 through FAK/PI3K/Rac1/mdm2 signaling. Int. J. Oncol. 2017, 50, 1821-1831. [CrossRef] [PubMed]

184. Zhao, H.; Li, M.; Li, L.; Yang, X.; Lan, G.; Zhang, Y. MiR-133b is down-regulated in human osteosarcoma and inhibits osteosarcoma cells proliferation, migration and invasion, and promotes apoptosis. PLOS ONE 2013, 8, e83571. [CrossRef] [PubMed]

185. Zha, R.; Guo, W.; Zhang, Z.; Qiu, Z.; Wang, Q.; Ding, J.; Huang, S.; Chen, T.; Gu, J.; Yao, M.; et al. Genome-wide screening identified that miR-134 acts as a metastasis suppressor by targeting integrin beta1 in hepatocellular carcinoma. PLoS ONE 2014, 9, e87665. [CrossRef] [PubMed]

186. Islam, M.; Datta, J.; Lang, J.C.; Teknos, T.N. Down regulation of RhoC by microRNA-138 results in de-activation of FAK, Src and Erk1/2 signaling pathway in head and neck squamous cell carcinoma. Oral Oncol. 2014, 50, 448-456. [CrossRef] [PubMed]

187. Qu, B.; Xia, X.; Wu, H.H.; Tu, C.Q.; Pan, X.M. PDGF-regulated miRNA-138 inhibits the osteogenic differentiation of mesenchymal stem cells. Biochem. Biophys. Res. Commun. 2014, 448, 241-247. [CrossRef] [PubMed]

188. Tanaka, K.; Kawano, M.; Itonaga, I.; Iwasaki, T.; Miyazaki, M.; Ikeda, S.; Tsumura, H. Tumor suppressive microRNA-138 inhibits metastatic potential via the targeting of focal adhesion kinase in Ewing's sarcoma cells. Int. J. Oncol. 2016, 48, 1135-1144. [CrossRef] [PubMed]

189. Wu, J.; Zhao, J.; Sun, L.; Pan, Y.; Wang, H.; Zhang, W.B. Long non-coding RNA H19 mediates mechanical tension-induced osteogenesis of bone marrow mesenchymal stem cells via FAK by sponging miR-138. Bone 2018, 108, 62-70. [CrossRef] [PubMed]

190. Zhang, F.; Yang, R.; Zhang, G.; Cheng, R.; Bai, Y.; Zhao, H.; Lu, X.; Li, H.; Chen, S.; Li, J.; et al. Anticancer function of alpha-solanine in lung adenocarcinoma cells by inducing microRNA-138 expression. Tumour Biol. 2016, 37, 6437-6446. [CrossRef] [PubMed]

191. Chen, X.; Wang, X.; Ruan, A.; Han, W.; Zhao, Y.; Lu, X.; Xiao, P.; Shi, H.; Wang, R.; Chen, L.; et al. miR-141 is a key regulator of renal cell carcinoma proliferation and metastasis by controlling EphA2 expression. Clin. Cancer Res. 2014, 20, 2617-2630. [CrossRef] [PubMed]

192. Choi, S.K.; Kim, H.S.; Jin, T.; Hwang, E.H.; Jung, M.; Moon, W.K. Overexpression of the miR-141/200c cluster promotes the migratory and invasive ability of triple-negative breast cancer cells through the activation of the FAK and PI3K/AKT signaling pathways by secreting VEGF-A. BMC Cancer 2016, 16, 570. [CrossRef] [PubMed]

193. Lee, H.K.; Bier, A.; Cazacu, S.; Finniss, S.; Xiang, C.; Twito, H.; Poisson, L.M.; Mikkelsen, T.; Slavin, S.; Jacoby, E.; et al. MicroRNA-145 is downregulated in glial tumors and regulates glioma cell migration by targeting connective tissue growth factor. PLOS ONE 2013, 8, e54652. [CrossRef] [PubMed]

194. Cao, M.; Hou, D.; Liang, H.; Gong, F.; Wang, Y.; Yan, X.; Jiang, X.; Wang, C.; Zhang, J.; Zen, K.; et al. miR-150 promotes the proliferation and migration of lung cancer cells by targeting SRC kinase signalling inhibitor 1. Eur. J. Cancer 2014, 50, 1013-1024. [CrossRef] [PubMed] 
195. Hsu, K.W.; Fang, W.L.; Huang, K.H.; Huang, T.T.; Lee, H.C.; Hsieh, R.H.; Chi, C.W.; Yeh, T.S. Notch1 pathway-mediated microRNA-151-5p promotes gastric cancer progression. Oncotarget 2016, 7, 38036-38051. [CrossRef] [PubMed]

196. Ding, J.; Huang, S.; Wu, S.; Zhao, Y.; Liang, L.; Yan, M.; Ge, C.; Yao, J.; Chen, T.; Wan, D.; et al. Gain of miR-151 on chromosome 8q24.3 facilitates tumour cell migration and spreading through downregulating RhoGDIA. Nat. Cell Biol. 2010, 12, 390-399. [CrossRef] [PubMed]

197. Luedde, T. MicroRNA-151 and its hosting gene FAK (focal adhesion kinase) regulate tumor cell migration and spreading of hepatocellular carcinoma. Hepatology 2010, 52, 1164-1166. [CrossRef] [PubMed]

198. Chao, A.; Lin, C.Y.; Lee, Y.S.; Tsai, C.L.; Wei, P.C.; Hsueh, S.; Wu, T.I.; Tsai, C.N.; Wang, C.J.; Chao, A.S.; et al. Regulation of ovarian cancer progression by microRNA-187 through targeting disabled homolog-2. Oncogene 2012, 31, 764-775. [CrossRef] [PubMed]

199. Li, W.; Wang, H.; Zhang, J.; Zhai, L.; Chen, W.; Zhao, C. miR-199a-5p regulates beta1 integrin through Ets-1 to suppress invasion in breast cancer. Cancer Sci. 2016, 107, 916-923. [CrossRef] [PubMed]

200. Meng, X.; Chen, X.; Lu, P.; Ma, W.; Yue, D.; Song, L.; Fan, Q. MicroRNA-202 inhibits tumor progression by targeting LAMA1 in esophageal squamous cell carcinoma. Biochem. Biophys. Res. Commun. 2016, 473, 821-827. [CrossRef] [PubMed]

201. Zhu, A.; Kang, N.; He, L.; Li, X.; Xu, X.; Zhang, H. MiR-221 and miR-26b Regulate Chemotactic Migration of MSCs Toward HGF Through Activation of Akt and FAK. J. Cell. Biochem. 2016, 117, 1370-1383. [CrossRef] [PubMed]

202. Fu, Q.; Song, X.; Liu, Z.; Deng, X.; Luo, R.; Ge, C.; Li, R.; Li, Z.; Zhao, M.; Chen, Y.; et al. miRomics and Proteomics Reveal a miR-296-3p/PRKCA/FAK/Ras/c-Myc Feedback Loop Modulated by HDGF/DDX5/beta-catenin Complex in Lung Adenocarcinoma. Clin. Cancer Res. 2017, 23, 6336-6350. [CrossRef] [PubMed]

203. He, L.; Wang, X.; Kang, N.; Xu, J.; Dai, N.; Xu, X.; Zhang, H. MiR-375 inhibits the hepatocyte growth factor-elicited migration of mesenchymal stem cells by downregulating Akt signaling. Cell Tissue Res. 2018. [CrossRef] [PubMed]

204. Zhao, L.N.; Wang, P.; Liu, Y.H.; Cai, H.; Ma, J.; Liu, L.B.; Xi, Z.; Li, Z.Q.; Liu, X.B.; Xue, Y.X. MiR-383 inhibits proliferation, migration and angiogenesis of glioma-exposed endothelial cells in vitro via VEGF-mediated FAK and Src signaling pathways. Cell Signal 2017, 30, 142-153. [CrossRef] [PubMed]

205. Fang, F.; Song, T.; Zhang, T.; Cui, Y.; Zhang, G.; Xiong, Q. MiR-425-5p promotes invasion and metastasis of hepatocellular carcinoma cells through SCAI-mediated dysregulation of multiple signaling pathways. Oncotarget 2017, 8, 31745-31757. [CrossRef] [PubMed]

206. Huang, W.C.; Chan, S.H.; Jang, T.H.; Chang, J.W.; Ko, Y.C.; Yen, T.C.; Chiang, S.L.; Chiang, W.F.; Shieh, T.Y.; Liao, C.T.; et al. miRNA-491-5p and GIT1 serve as modulators and biomarkers for oral squamous cell carcinoma invasion and metastasis. Cancer Res 2014, 74, 751-764. [CrossRef] [PubMed]

207. Oneyama, C.; Morii, E.; Okuzaki, D.; Takahashi, Y.; Ikeda, J.; Wakabayashi, N.; Akamatsu, H.; Tsujimoto, M.; Nishida, T.; Aozasa, K.; et al. MicroRNA-mediated upregulation of integrin-linked kinase promotes Src-induced tumor progression. Oncogene 2012, 31, 1623-1635. [CrossRef] [PubMed]

208. Cao, W.; Wei, W.; Zhan, Z.; Xie, D.; Xie, Y.; Xiao, Q. Regulation of drug resistance and metastasis of gastric cancer cells via the microRNA647-ANK2 axis. Int. J. Mol. Med. 2018, 41, 1958-1966. [CrossRef] [PubMed]

209. Cao, W.; Wei, W.; Zhan, Z.; Xie, D.; Xie, Y.; Xiao, Q. Role of miR-647 in human gastric cancer suppression. Oncol. Rep. 2017, 37, 1401-1411. [CrossRef] [PubMed]

210. Ryu, S.; McDonnell, K.; Choi, H.; Gao, D.; Hahn, M.; Joshi, N.; Park, S.-M.; Catena, R.; Do, Y.; Brazin, J.; et al. Suppression of miRNA-708 by polycomb group promotes metastases by calcium-induced cell migration. Cancer Cell 2013, 23, 63-76. [CrossRef] [PubMed]

211. Liu, R.F.; Xu, X.; Huang, J.; Fei, Q.L.; Chen, F.; Li, Y.D.; Han, Z.G. Down-regulation of miR-517a and miR-517c promotes proliferation of hepatocellular carcinoma cells via targeting Pyk2. Cancer Lett. 2013, 329, 164-173. [CrossRef] [PubMed]

212. Gutschner, T.; Diederichs, S. The hallmarks of cancer: A long non-coding RNA point of view. RNA Biol. 2012, 9, 703-719. [CrossRef] [PubMed]

213. Li, Y.; Wu, Z.; Yuan, J.; Sun, L.; Lin, L.; Huang, N.; Bin, J.; Liao, Y.; Liao, W. Long non-coding RNA MALAT1 promotes gastric cancer tumorigenicity and metastasis by regulating vasculogenic mimicry and angiogenesis. Cancer Lett. 2017, 395, 31-44. [CrossRef] [PubMed] 
214. Liang, Y.; Chen, X.; Wu, Y.; Li, J.; Zhang, S.; Wang, K.; Guan, X.; Yang, K.; Bai, Y. LncRNA CASC9 promotes esophageal squamous cell carcinoma metastasis through upregulating LAMC2 expression by interacting with the CREB-binding protein. Cell Death Differ. 2018. [CrossRef] [PubMed]

215. Lv, P.C.; Jiang, A.Q.; Zhang, W.M.; Zhu, H.L. FAK inhibitors in cancer, a patent review. Expert Opin. Ther. Pat. 2018, 28, 139-145. [CrossRef] [PubMed]

216. Duncan, J.S.; Whittle, M.C.; Nakamura, K.; Abell, A.N.; Midland, A.A.; Zawistowski, J.S.; Johnson, N.L.; Granger, D.A.; Jordan, N.V.; Darr, D.B.; et al. Dynamic Reprogramming of the Kinome in Response to Targeted MEK Inhibition in Triple-Negative Breast Cancer. Cell 2012, 149, 307-321. [CrossRef] [PubMed]

217. Graves, L.M.; Duncan, J.S.; Whittle, M.C.; Johnson, G.L. The dynamic nature of the kinome. Biochem. J. 2013, 450, 1-8. [CrossRef] [PubMed]

218. Golubovskaya, V.M.; Ho, B.; Zheng, M.; Magis, A.; Ostrov, D.; Morrison, C.; Cance, W.G. Disruption of focal adhesion kinase and p53 interaction with small molecule compound R2 reactivated p53 and blocked tumor growth. BMC Cancer 2013, 13, 342. [CrossRef] [PubMed]

219. Tomita, N.; Hayashi, Y.; Suzuki, S.; Oomori, Y.; Aramaki, Y.; Matsushita, Y.; Iwatani, M.; Iwata, H.; Okabe, A.; Awazu, Y.; et al. Structure-based discovery of cellular-active allosteric inhibitors of FAK. Bioorg. Med. Chem. Lett. 2013, 23, 1779-1785. [CrossRef] [PubMed]

220. Heinrich, T.; Seenisamy, J.; Emmanuvel, L.; Kulkarni, S.S.; Bomke, J.; Rohdich, F.; Greiner, H.; Esdar, C.; Krier, M.; Grädler, U.; et al. Fragment-Based Discovery of New Highly Substituted 1H-Pyrrolo[2,3-b]- and 3H-Imidazolo[4,5-b]-Pyridines as Focal Adhesion Kinase Inhibitors. J. Med. Chem. 2013, 56, 1160-1170. [CrossRef] [PubMed]

221. Golubovskaya, V.M.; Figel, S.; Ho, B.T.; Johnson, C.P.; Yemma, M.; Huang, G.; Zheng, M.; Nyberg, C.; Magis, A.; Ostrov, D.A.; et al. A small molecule focal adhesion kinase (FAK) inhibitor, targeting Y397 site: 1-(2-hydroxyethyl)-3,5,7-triaza-1-azoniatricyclo [3.3.1.1(3,7)]decane; bromide effectively inhibits FAK autophosphorylation activity and decreases cancer cell viability, clonogenicity and tumor growth in vivo. Carcinogenesis 2012, 33, 1004-1013. [CrossRef] [PubMed]

222. Cance, W.G.; Kurenova, E.; Marlowe, T.; Golubovskaya, V. Disrupting the scaffold to improve focal adhesion kinase-targeted cancer therapeutics. Sci. Signal. 2013, 6, pe10. [CrossRef] [PubMed]

223. Schultheis, B.; Strumberg, D.; Santel, A.; Vank, C.; Gebhardt, F.; Keil, O.; Lange, C.; Giese, K.; Kaufmann, J.; Khan, M.; et al. First-in-Human Phase I Study of the Liposomal RNA Interference Therapeutic Atu027 in Patients With Advanced Solid Tumors. J. Clin. Oncol. 2014, 32, 4141-4148. [CrossRef] [PubMed]

224. Watts, J.K.; Corey, D.R. Clinical status of duplex RNA. Bioorg. Med. Chem. Lett. 2010, 20, 3203-3207. [CrossRef] [PubMed]

225. Hon, C.-C.; Ramilowski, J.A.; Harshbarger, J.; Bertin, N.; Rackham, O.J.L.; Gough, J.; Denisenko, E.; Schmeier, S.; Poulsen, T.M.; Severin, J.; et al. An atlas of human long non-coding RNAs with accurate $5^{\prime}$ ends. Nature 2017, 543, 199-204. [CrossRef] [PubMed]

226. Li, T.; Mo, X.; Fu, L.; Xiao, B.; Guo, J. Molecular mechanisms of long noncoding RNAs on gastric cancer. Oncotarget 2016, 7, 8601-8612. [CrossRef] [PubMed]

227. Tesmer, V.M.; Lennarz, S.; Mayer, G.; Tesmer, J.J.G. Molecular mechanism for inhibition of G protein-coupled receptor kinase 2 by a selective RNA aptamer. Struct. Lond. Engl. 1993 2012, 20, 1300-1309. [CrossRef] [PubMed]

228. Marondedze, C.; Thomas, L.; Serrano, N.L.; Lilley, K.S.; Gehring, C. The RNA-binding protein repertoire of Arabidopsis thaliana. Sci. Rep. 2016, 6, 29766. [CrossRef] [PubMed]

229. Chen, Y.; Gao, D.-Y.; Huang, L. In vivo delivery of miRNAs for cancer therapy: Challenges and strategies. Adv. Drug Deliv. Rev. 2015, 81, 128-141. [CrossRef] [PubMed]

230. Ho, P.Y.; Duan, Z.; Batra, N.; Jilek, J.L.; Tu, M.-J.; Qiu, J.-X.; Hu, Z.; Wun, T.; Lara, P.N.; DeVere White, R.W.; et al. Bioengineered ncRNAs selectively change cellular miRNome profiles for cancer therapy. J. Pharmacol. Exp. Ther. 2018. [CrossRef] [PubMed]

231. Dourlen, P.; Fernandez-Gomez, F.J.; Dupont, C.; Grenier-Boley, B.; Bellenguez, C.; Obriot, H.; Caillierez, R.; Sottejeau, Y.; Chapuis, J.; Bretteville, A.; et al. Functional screening of Alzheimer risk loci identifies PTK2B as an in vivo modulator and early marker of Tau pathology. Mol. Psychiatry 2017, 22, 874-883. [CrossRef] [PubMed] 
232. Giralt, A.; Brito, V.; Chevy, Q.; Simonnet, C.; Otsu, Y.; Cifuentes-Díaz, C.; de Pins, B.; Coura, R.; Alberch, J.; Ginés, S.; et al. Pyk2 modulates hippocampal excitatory synapses and contributes to cognitive deficits in a Huntington's disease model. Nat. Commun. 2017, 8, 15592. [CrossRef] [PubMed]

233. Giralt, A.; de Pins, B.; Cifuentes-Díaz, C.; López-Molina, L.; Farah, A.T.; Tible, M.; Deramecourt, V.; Arold, S.; Ginés, S.; Hugon, J.; et al. PTK2B/Pyk2 overexpression improves a mouse model of Alzheimer's disease. Exp. Neurol. 2018, 307, 62-73. [CrossRef] [PubMed]

(C) 2018 by the authors. Licensee MDPI, Basel, Switzerland. This article is an open access article distributed under the terms and conditions of the Creative Commons Attribution (CC BY) license (http://creativecommons.org/licenses/by/4.0/). 